\title{
Decoupled redox catalytic hydrogen production with a robust electrolyte-borne electron and proton carrier
}

Feifei Zhang, ${ }^{1 \dagger}$ Hang Zhang, ${ }^{1 \dagger}$ Manohar Salla, ${ }^{1}$ Ning Qin, ${ }^{2}$ Mengqi Gao, ${ }^{1}$ Ya Ji, ${ }^{1}$ Shiqiang Huang, ${ }^{1}$ Sisi Wu, ${ }^{1,2}$ Ruifeng Zhang, ${ }^{3}$ Zhouguang $\mathrm{Lu},{ }^{*, 2}$ and Qing Wang ${ }^{*, 1}$

${ }^{1}$ Department of Materials Science and Engineering, Faculty of Engineering, National University of Singapore, Singapore 117576

${ }^{2}$ Department of Materials Science and Engineering, Southern University of Science and Technology, Shenzhen, 518055 P. R. China

${ }^{3}$ School of Materials Science and Engineering, Beihang University, Beijing 100191, P. R. China

* Corresponding author.

E-mail address:msewq@nus.edu.sg (Q.Wang),luzg@sustech.edu.cn (Z.Lu) 


\section{Index}

I. Materials synthesis and characterizations $\quad$ Page 3-5

II. Cyclic voltammetry tests of redox mediators $\quad$ Page 6-7

$\begin{array}{ll}\text { III. Catalysts characterizations } & \text { Page 8-11 }\end{array}$

IV. Hydrogen and oxygen production during decoupled water splitting $\quad$ Page 12

$\begin{array}{ll}\text { V. GITT test of the redox flow cell } & \text { Page } 13\end{array}$

VI. Comparison of two different anion-exchange membranes $\quad$ Page 14

VII. Operando UV-vis spectroscopic measurement $\quad$ Page 15-16

$\begin{array}{lr}\text { VIII. Comparison of decoupled and direct water splitting } & \text { Page } 17\end{array}$

IX. DFT calculations of DHPS-mediated HER reaction Page 18-22

X. EPR measurement of DHPS-2H upon dehydrogenation Page 23

XI. NMR measurement of DHPS-2H upon dehydrogenation Page 24-26

XII. Comparison of different decoupled water splitting methods $\quad$ Page 27

$\begin{array}{lr}\text { XIII. References } & \text { Page } 28\end{array}$ 


\section{Materials synthesis and characterizations}

\section{Materials.}

All the chemicals and reagents were purchased from commercial suppliers and used without further purification. Benzene-1,2-daimine, 2,5-dihydroxy-1,4-benzoquinone, $\mathrm{K}_{2} \mathrm{PtCl}_{4}$, $\mathrm{Ni}\left(\mathrm{NO}_{3}\right)_{2} \cdot 6 \mathrm{H}_{2} \mathrm{O}, \mathrm{Fe}\left(\mathrm{NO}_{3}\right)_{3} \cdot 9 \mathrm{H}_{2} \mathrm{O}, \mathrm{NaOH}$ were purchased from Sigma-Aldrich. $\mathrm{HCl}$ and $\mathrm{H}_{2} \mathrm{SO}_{4}$ were purchased from Alfa Aesar. 10\% wt. Platinum on carbon was purchased from Fuel Cell Earth. Carbon felt was purchased form Tieling Shenhe Carbon Fiber Material Company. Anionexchange membrane (Fumasep FAAM-15) was purchased from Fuel Cell Store. Anionexchange membrane (Sustainion ${ }^{\circledR}$ X37-50 membrane) was purchased from Dioxide Materials.

\section{DHPS Synthesis and Characterizations.}

\section{(1) Synthesis of 3,4-Diaminobenzenesulfonic acid.}<smiles>Nc1ccccc1N</smiles><smiles>[Mg][Mg]</smiles><smiles>Nc1ccc(S(=O)(=O)O)cc1N</smiles>

In a round bottom flask, benzene-1,2-daimine $(20.0 \mathrm{~g}, 185 \mathrm{mmol})$ was added portion wise to con. $\mathrm{H}_{2} \mathrm{SO}_{4}(110 \mathrm{~mL})$ over a period of 30 minutes. The resulting turbid solution was stirred for 30 minutes at room temperature to obtain a limpid solution. After that, the reaction mixture was heated at $140{ }^{\circ} \mathrm{C}$ for 20 hours. The reaction mixture was cooled to $0{ }^{\circ} \mathrm{C}$ and ice-cold water (ca. $200 \mathrm{~mL}$ ) was added slowly until the product precipitate as an off-white solid. The solid which appeared was filtered by vacuum filtration and dried for two hours. The solid was transferred to a round bottom flask and added deionized water $(100 \mathrm{~mL})$. The turbid was stirred for 60 minutes, filtered and dried to get desired compound as an off-white solid $(19.8 \mathrm{~g}, 58 \%) .{ }^{1} \mathrm{H}$ NMR- (400 MHz, DMSO-d $) \delta 7.39(1 \mathrm{H}, \mathrm{d}, J=1.8 \mathrm{~Hz}), 7.19\left(1 \mathrm{H}, \mathrm{dd}, J_{l}=8.4 \mathrm{~Hz}, J_{2}=1.8 \mathrm{~Hz}\right)$, $6.86(1 \mathrm{H}, \mathrm{d}, J=8.4 \mathrm{~Hz})$. (Note: Amine and sulfonic acid protons observed as a broad hump and merged with aromatic protons)

(2) Synthesis and characterizations of 7, 8-Dihydroxy-2-phenazinesulfonic acid (DHPS) ${ }^{1}$.<smiles>Nc1ccc(S(=O)(=O)O)cc1N</smiles>

In a round bottom flask, deionized water $(130 \mathrm{~mL})$ was heated to $105^{\circ} \mathrm{C}$ in an oil bath. While warming the water, 2,5-dihydroxy-1,4-benzoquinone $(8.27 \mathrm{~g}, 59.0 \mathrm{mmol})$ was added portionwise and stirred for 5 minutes at $105^{\circ} \mathrm{C}$. Then, 3,4-diaminobenzenesulfonic acid (11.1 g, 59.0 mmol) was added portion-wise over a 5 minutes period. The resulting dark brown reaction mixture was heated to reflux for overnight ( $c a .16$ hours). The reaction mixture was cooled to room temperature and diluted with acetone $(150 \mathrm{~mL})$. The solid was filtered by vacuum filtration, washed with water $(3 \times 50 \mathrm{~mL})$ and acetone $(3 \times 50 \mathrm{~mL})$. The solid was dried using vacuum for two days and subsequently dried under reduced pressure using a rotary evaporator at $50{ }^{\circ} \mathrm{C}$ for 2 hours to obtain the DHPS as dark gold color solid (14.8 g, 86\%). ${ }^{1} \mathrm{H}-\mathrm{NMR}$ (400 
MHz, DMSO- $\left.d_{6}\right) \delta: 8.30(\mathrm{~s} 1 \mathrm{H}), 8.14(\mathrm{~d}, J=8.2 \mathrm{~Hz}, 1 \mathrm{H}), 8.06(\mathrm{~d}, J=8.2 \mathrm{~Hz}, 1 \mathrm{H}), 7.37(\mathrm{~s} 1 \mathrm{H})$, $7.35(\mathrm{~s} 1 \mathrm{H})$ (Note: The acidic protons $\left(\mathrm{OH}, \mathrm{SO}_{3} \mathrm{H}\right)$ were observed as a broad hump from $\delta 8.8$ - 8.4). ${ }^{13} \mathrm{C}-\mathrm{NMR}\left(100 \mathrm{MHz}, \mathrm{DMSO}-d_{6}\right) \delta: 157.4,156.6,149.4,140.3,138.9,137.1,135.1,128.3$, $126.1,120.8,105.3,104.1$.

${ }^{1} \mathrm{H}$ NMR spectroscopic measurements were performed on Bruker $400 \mathrm{MHz}$ spectrometers. The NMR spectra were recorded in solutions of deuterated dimethyl sulfoxide (DMSO- $\mathrm{d}_{6}$ ) with residual DMSO (2.49 ppm for ${ }^{1} \mathrm{H}-\mathrm{NMR}$ ) taken as the internal standard. Where necessary, NMR spectra were recorded on Bruker $500 \mathrm{MHz}$ spectrometer using aqueous samples with $10 \% \mathrm{D}_{2} \mathrm{O}$ and suppressed the water signal. The chemical shifts were expressed in parts per million $(\delta)$.
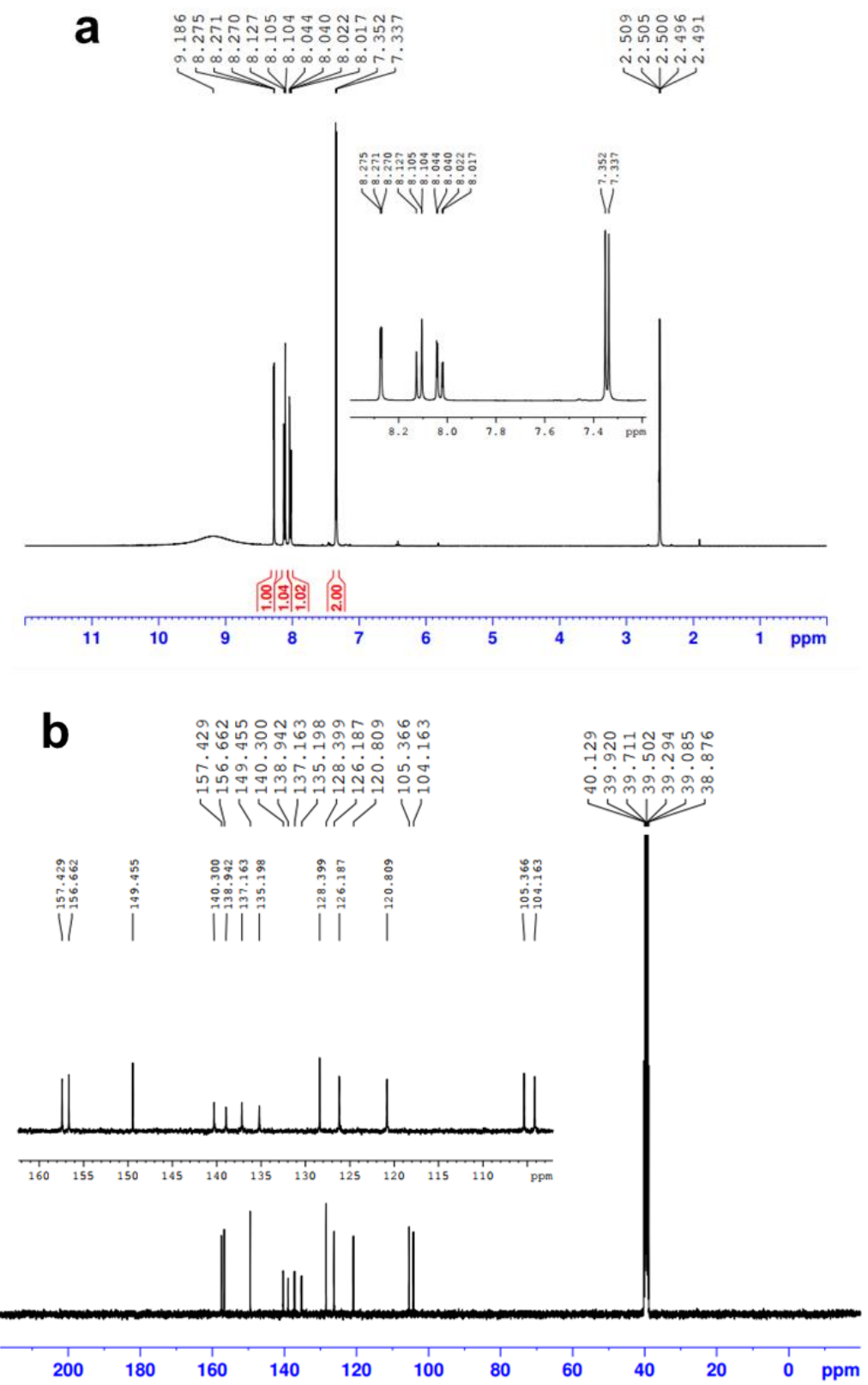

Figure S1. (a) ${ }^{1} \mathrm{H}-\mathrm{NMR}$ spectrum of DHPS recorded in DMSO- $d_{6}$. (b) ${ }^{13} \mathrm{C}-\mathrm{NMR}$ spectrum of DHPS recorded in DMSO- $d_{6}$. 


\section{Catalysts Synthesis and characterizations.}

(1) Synthesis of hierarchical $\mathrm{Ni}(\mathrm{OH})_{2}$ nanosheets substrate: Firstly, 5 pieces of $\mathrm{Ni}$ foam $(3 \times$ $2 \mathrm{~cm}^{2}$ ) were immersed in $1 \mathrm{M} \mathrm{HCl}$ under ultrasonic treatment to wash away the oxidation layer on the surface. Then, the Ni substrates were rinsed with deionized (DI) water and transferred to a sealed glass bottle containing $80 \mathrm{~mL} 0.11 \mathrm{mM} \mathrm{HCl}$ aqueous solution. This solution was heated at $80{ }^{\circ} \mathrm{C}$ under stirring for $20 \mathrm{~h}$. The substrates were washed with DI water and dried in a vacuum oven at $50{ }^{\circ} \mathrm{C}$.

(2) Electrodeposition of Pt nanoparticle: The electrochemical deposition was conducted in a three-electrode electrochemical system, using $20 \mathrm{~mL} 1 \mathrm{M} \mathrm{KOH}$ solution containing $200 \mu \mathrm{L}$ $\mathrm{K}_{2} \mathrm{PtCl}_{4}(60 \mathrm{mM})$ as the electrolyte. The $\mathrm{Ni}(\mathrm{OH})_{2}$ substrate, graphite rod, and $\mathrm{Hg} / \mathrm{HgO}$ electrode were used as working, counter and reference electrodes, respectively. The electrochemical deposition was performed by cyclic voltammetry in potential range from -0.9 to $-1.9 \mathrm{~V}$ vs. $\mathrm{Hg} / \mathrm{HgO}$ for 50 cycles at a sweep rate of $5 \mathrm{mV} \mathrm{s}^{-1}$.

(3) Synthesis of hierarchical Fe-doped $\mathrm{Ni}(\mathrm{OH})_{2}$ nanosheets: For $\mathrm{NiFe}(\mathrm{OH})_{2}$ growth, a piece of $\mathrm{HCl}$-treated $\mathrm{Ni}$ foam was treated for the preparation of $\mathrm{Ni}(\mathrm{OH})_{2}$ nanosheets. Then, the $\mathrm{Ni}$ foam were transferred to a sealed glass bottle filled with $0.1 \mathrm{mM} \mathrm{HCl}$ and $0.01 \mathrm{mM}$ $\mathrm{Fe}\left(\mathrm{NO}_{3}\right)_{3} \cdot 9 \mathrm{H}_{2} \mathrm{O}$ under stirring and heated at $80{ }^{\circ} \mathrm{C}$ for $20 \mathrm{~h}$.

(4) Supplemental materials characterizations: The morphology and microstructure of the synthesized materials were characterized by a Zeiss Supra 40 field-emission scanning electron microscope (FESEM) at $5 \mathrm{kV}$. Energy dispersive X-ray spectroscopy (EDX) was recorded at an acceleration voltage of $15 \mathrm{kV}$. The X-ray photoelectron spectroscopy (XPS) analysis was conducted with a Kratos Analytical Axis Ultra DLD spectrometer. Monochromated Al K radiation was used as the radiation source, and all the measurements were carried out in vacuum. The catalyst was directly used for FESEM, EDX and XPS characterizations without any preparation. Transmission electron microscopy (TEM) measurement was performed on a JEOL-3010 (300 kV acceleration voltage). The samples were ultrasonically dispersed in ethanol for 1 hour and dripped the supernatant onto a copper grid. 


\section{Cyclic voltammetry tests of redox mediators}

The electrochemical properties of DHPS and $\mathrm{Fe}(\mathrm{CN})_{6}{ }^{4-3-3-}$ were analyzed by cyclic voltammetry (CV) in $4.0 \mathrm{M} \mathrm{NaOH}$ aqueous solution on an Autolab electrochemical workstation (Metrohm, PSTA30) with a 3-electrode cell system. Glassy carbon, graphite rod and $\mathrm{Hg} / \mathrm{HgO}$ were used as working, counter and reference electrodes, respectively. For the CV test of DHPS, the cells were sealed and protected by $\mathrm{N}_{2}$.
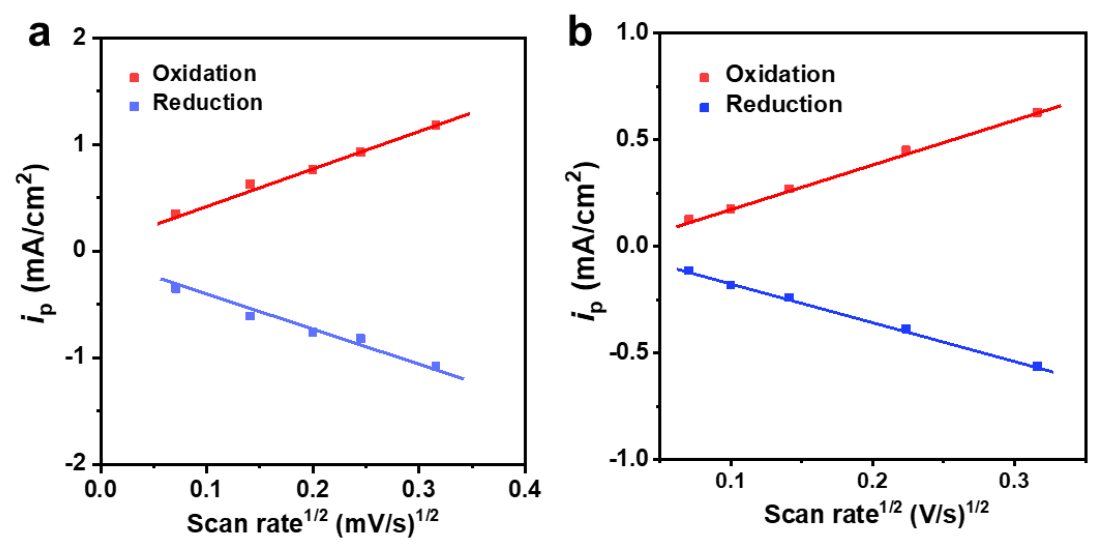

Figure S2. Peak current vs. the square root of scan rate for (a) $5 \mathrm{mM} \mathrm{K}_{3}\left[\mathrm{Fe}(\mathrm{CN})_{6}\right] / \mathrm{K}_{4}\left[\mathrm{Fe}(\mathrm{CN})_{6}\right]$ and (b) $5 \mathrm{mM}$ DHPS in $4 \mathrm{M} \mathrm{NaOH}$ solution at different scan rates.

The peak currents at different scan rate follow a linear relation with the square root of the scan rate for both the oxidation and reduction reactions, indicating a diffusion-controlled and electrochemically reversible process. The diffusion coefficient could be determined with the Randles-Sevcik equation ${ }^{2}$ below:

$$
I_{P}=2.69 \times 10^{5} n^{3 / 2} A D^{1 / 2} C v^{1 / 2}
$$

in which $I_{P}$ is the peak current in ampere, $n$ is the number of electrons transferred (assumed to be two for DHPS, one for $\left.\left[\mathrm{Fe}(\mathrm{CN})_{6}\right]^{4-/ 3-}\right), A$ is the electrode area in $\mathrm{cm}^{2}, D$ is the diffusion coefficient in $\mathrm{cm}^{2} / \mathrm{s}, C$ is the electrolyte concentration in $\mathrm{mol} / \mathrm{cm}^{3}, v$ is the scan rate in $\mathrm{V} / \mathrm{s}$. The diffusion coefficient of DHPS and $\left[\mathrm{Fe}(\mathrm{CN})_{6}\right]^{4-3-}$ were calculated to be $7.5 \times 10^{-7}$ and $2.5 \times 10^{-6}$ $\mathrm{cm}^{2} / \mathrm{s}$, respectively. 


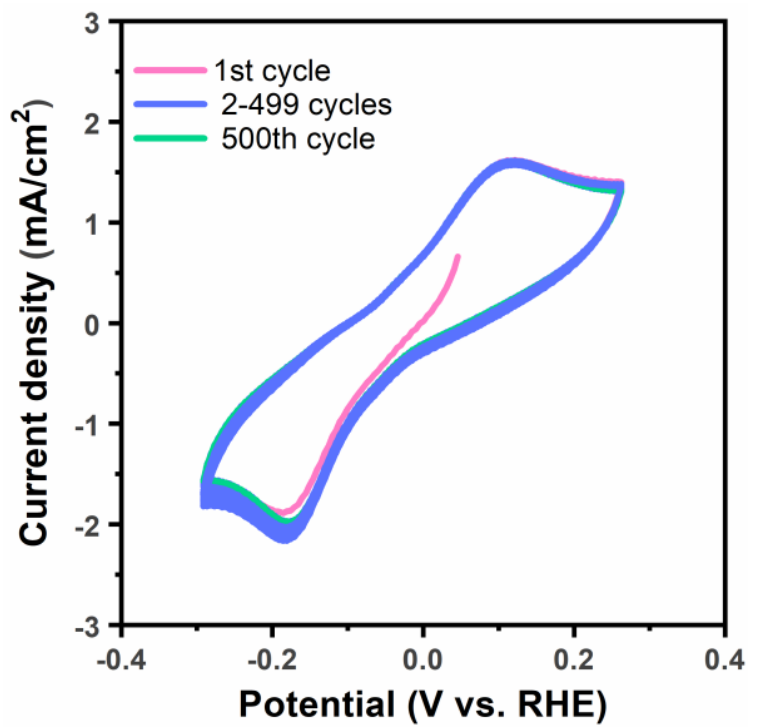

Figure S3. CV curves of $5 \mathrm{mM}$ DHPS in $4 \mathrm{M} \mathrm{NaOH}$ solution at $0.1 \mathrm{~V} / \mathrm{s}$ for 500 cycles. It retained near unchanged after 500 consecutive cycles in alkaline solution, indicating excellent electrochemical stability of DHPS. 


\section{Catalyst characterizations}

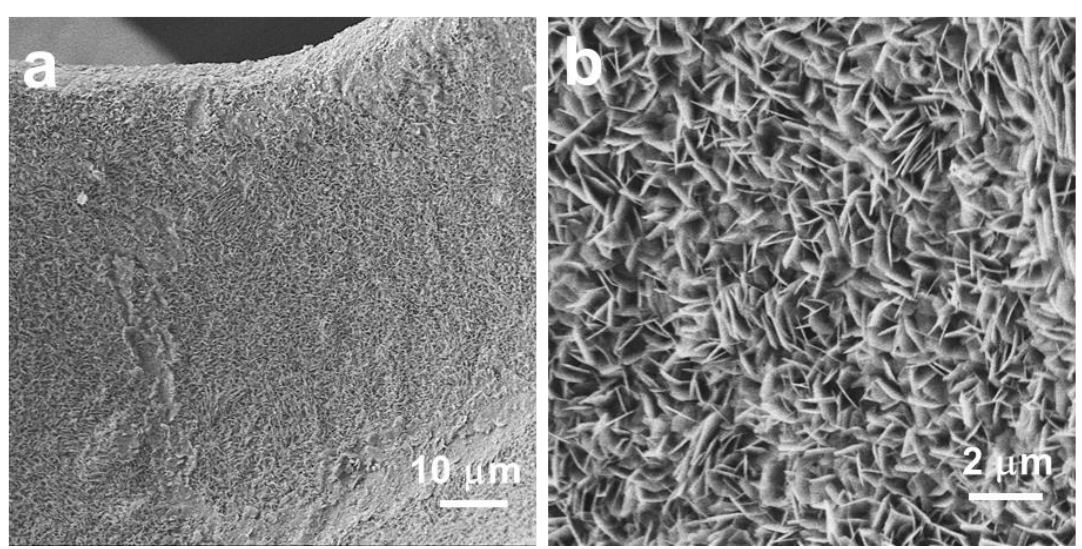

Figure S4. SEM images of the $\mathrm{Ni}(\mathrm{OH})_{2}$ substrate on Ni foam.

For the synthesis of $\mathrm{Pt}-\mathrm{Ni}(\mathrm{OH})_{2}$, a uniform network composed of interwoven ultrathin $\mathrm{Ni}(\mathrm{OH})_{2}$ nanosheets (Figure S4) was firstly grown on Ni foam substrate through an in-situ acid-etching method.

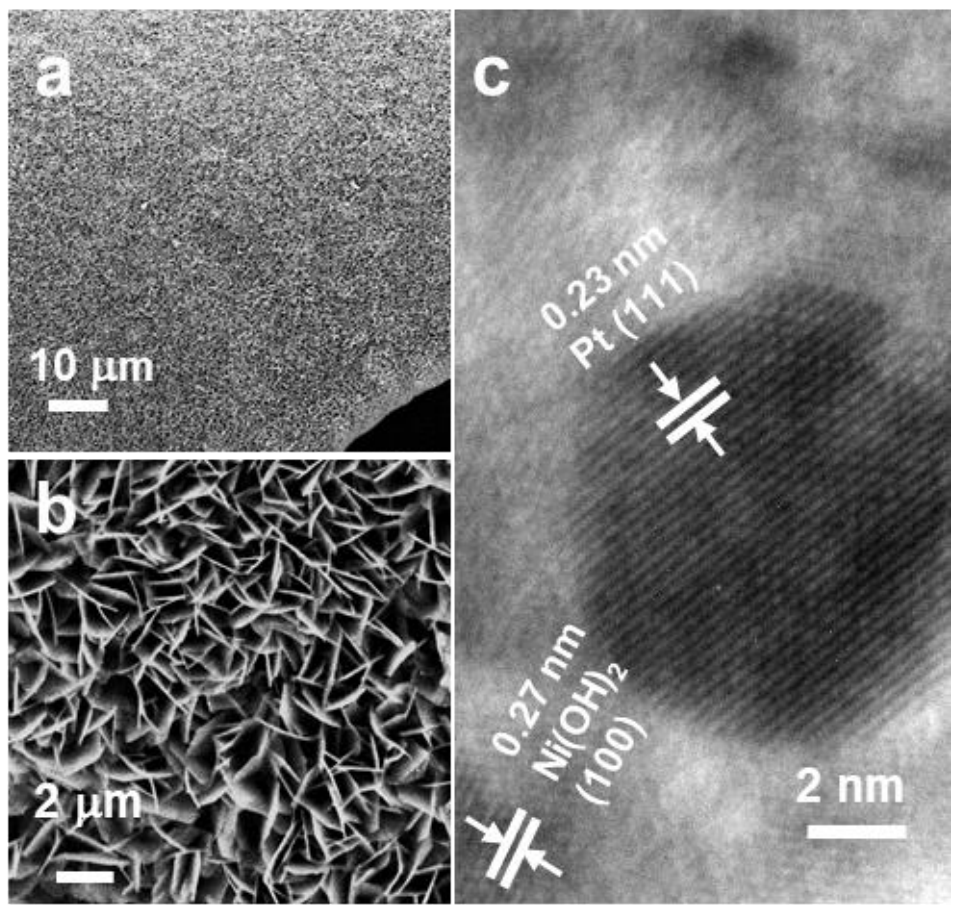

Figure S5 (a, b) SEM and (c) TEM images of Pt-Ni(OH) $)_{2}$ Ni foam. 

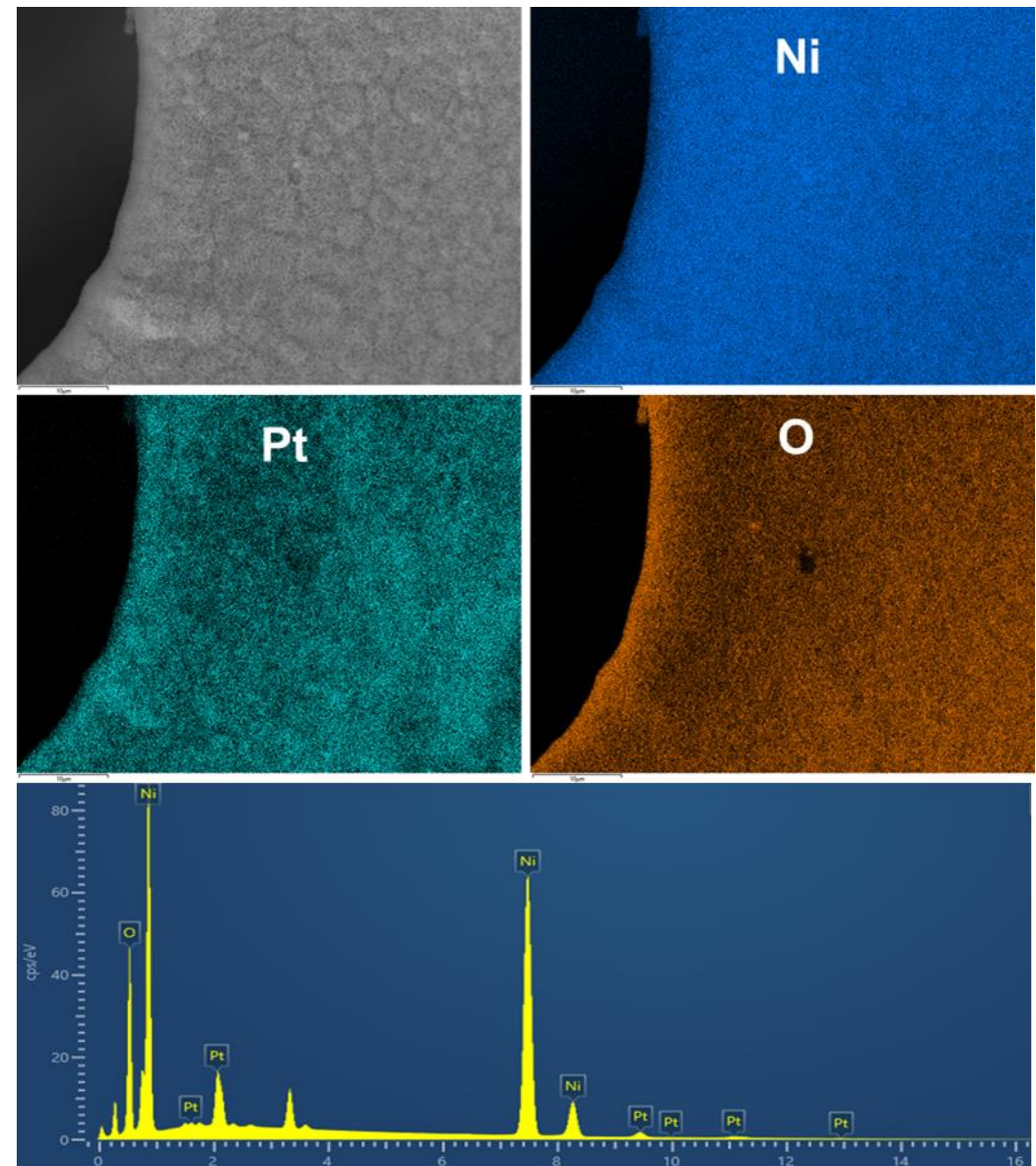

Figure S6. EDS mapping and EDX spectrum of $\mathrm{Pt}-\mathrm{Ni}(\mathrm{OH})_{2}$.

Pt nanoparticles of $\sim 6 \mathrm{~nm}$ in diameter were then uniformly deposited on $\mathrm{Ni}(\mathrm{OH})_{2}$ via a potential scan method (Figure S5a-c). The nanosheet structure is advantageous to electrolyte permeation and release of formed $\mathrm{H}_{2}$ gas for catalytic HER reaction. TEM shows the nanoparticles have a lattice spacing of $\sim 0.23 \mathrm{~nm}$ consistent with the (111) plane of metallic $\mathrm{Pt}$, and the surrounding substrate has a lattice spacing of $\sim 0.27 \mathrm{~nm}$ consistent with the (110) plane of $\mathrm{Ni}(\mathrm{OH})_{2}$. Energy dispersive X-ray spectroscopy (EDS) mapping analysis also confirms the homogeneous dispersion of Pt (Figure S6). 


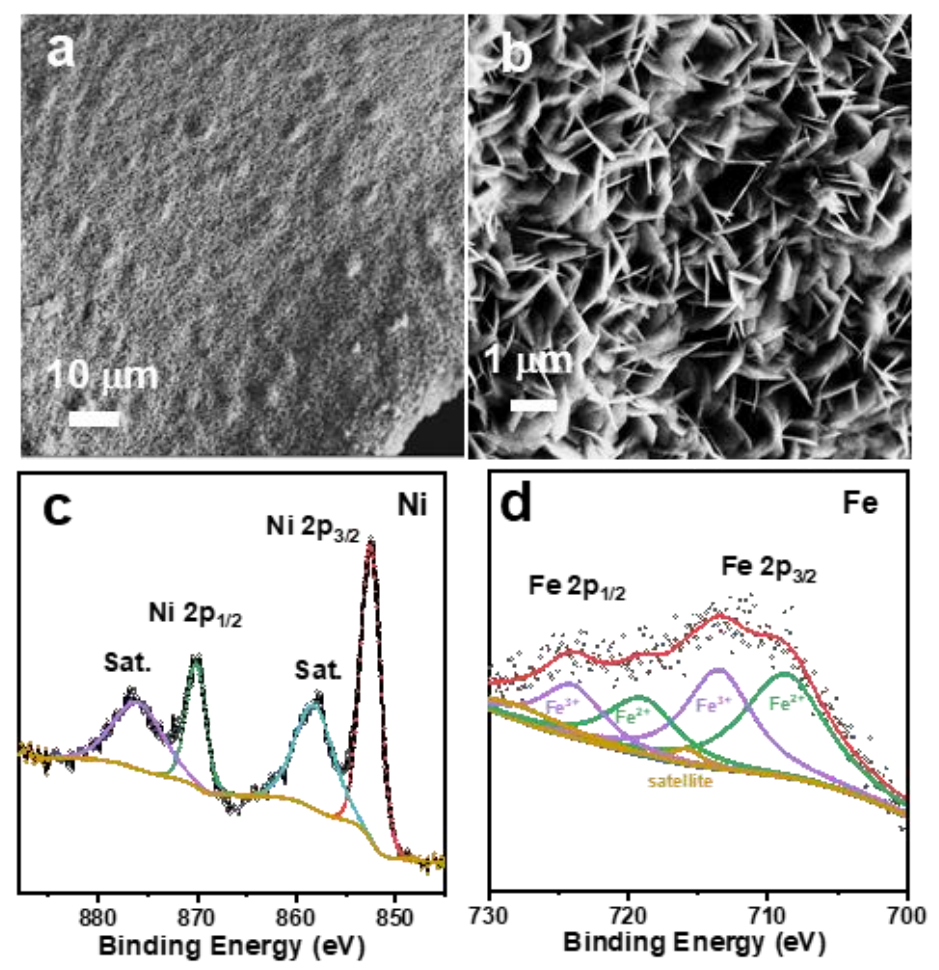

Figure S7. $(\mathrm{a}, \mathrm{b}) \mathrm{SEM}$ images and (c) XPS spectra of $\mathrm{NiFe}(\mathrm{OH})_{2} @ \mathrm{Ni}$ foam.

In comparison, porous and nanocrystalline flakes of $\mathrm{NiFe}(\mathrm{OH})_{2}$ was synthesized on $\mathrm{Ni}$ foam through a facile self-regulated acid-etching method. ${ }^{3}$ SEM images (Figure S7a, b) show similar interwoven ultrathin nanosheets grown on $\mathrm{Ni}$ foam network. The composition and element chemical state of $\mathrm{NiFe}(\mathrm{OH})_{2}$ was confirmed by X-ray photoelectron spectroscopy (XPS). The $\mathrm{Ni}$ spectrum (Figure S7c) consists of two main peaks with binding energies at 852.6 (Ni 2 $\mathrm{p}_{3 / 2}$ ) and $870.2 \mathrm{eV}\left(\mathrm{Ni} 2 \mathrm{p}_{1 / 2}\right.$ ), with a spin-energy separation of $17.6 \mathrm{eV}$, which is characteristic for $\mathrm{Ni}(\mathrm{OH})_{2}$ phase and in good agreement with previously reported data. ${ }^{4-5}$ The peaks at 876.9 and $858.3 \mathrm{eV}$ around $\mathrm{Ni} 2 \mathrm{p}_{1 / 2}$ and $\mathrm{Ni} 2 \mathrm{p}_{3 / 2}$ signals are marked as satellite peaks. The Fe spectrum exhibits two sets of typical 2p peaks of $\mathrm{Fe}^{2+}$ (708.7 and 719.2 eV), and $\mathrm{Fe}^{3+}(713.5$ and 724.0 $\mathrm{eV}$ ) ions which verifies the presence of $\mathrm{Fe}^{3}$
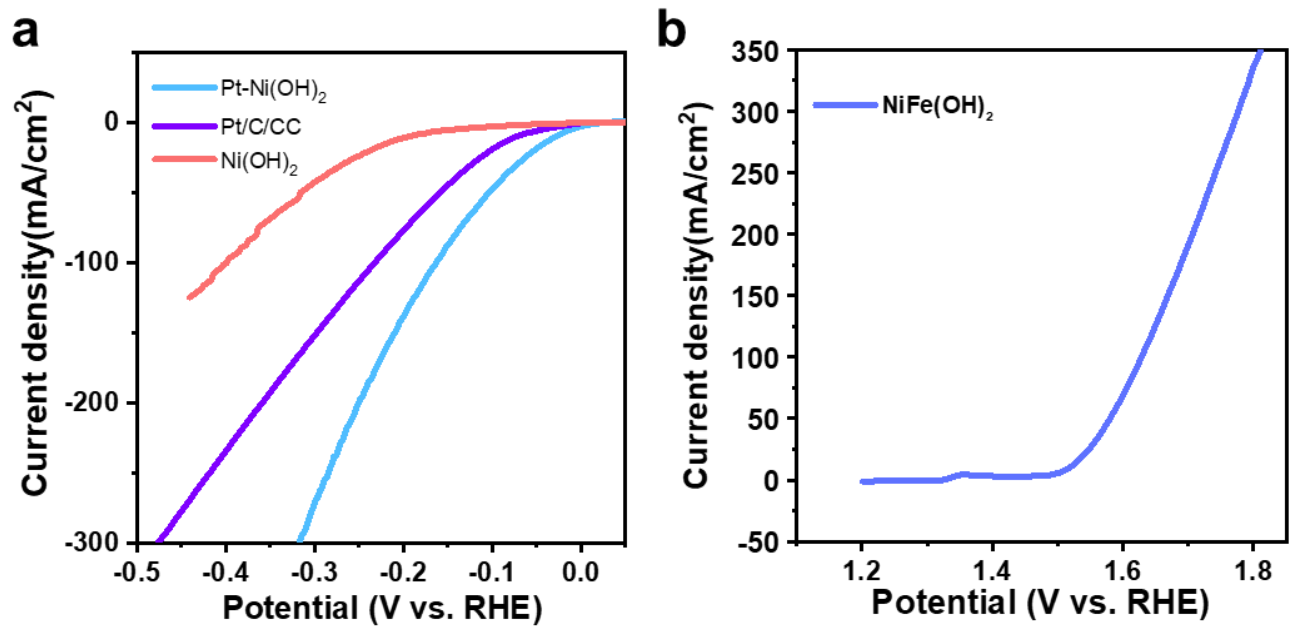
Figure S8. (a) LSV curves of $\mathrm{Ni}(\mathrm{OH})_{2}, \mathrm{Pt} / \mathrm{C}$ and $\mathrm{Pt}-\mathrm{Ni}(\mathrm{OH})_{2}$ and (b) $\mathrm{NiFe}(\mathrm{OH})_{2}$ in $4 \mathrm{M} \mathrm{NaOH}$ solution. The scan rate was $1 \mathrm{mV} / \mathrm{s}$. The counter electrode was carbon rod and the reference electrode was $\mathrm{Hg} / \mathrm{HgO}$ electrode. The $\mathrm{Pt} / \mathrm{C}-\mathrm{CC}$ electrode was prepared by coating commercial $10 \% \mathrm{Pt} / \mathrm{C}$ powder on the carbon cloth (CC), and the binder was $5 \%$ Nafion solution.

The catalytic properties of $\mathrm{Pt}-\mathrm{Ni}(\mathrm{OH})_{2}$ and $\mathrm{NiFe}(\mathrm{OH})_{2}$ towards HER and OER reactions were examined by LSV and CV measurements in $4 \mathrm{M} \mathrm{NaOH}$ electrolyte (Figure S8). The reductive sweep curve of the Pt-Ni(OH $)_{2}$ catalyst exhibits an onset overpotential of $\sim 10 \mathrm{mV}$ vs. RHE, followed by a sharp current enhancement corresponding to $\mathrm{H}_{2}$ evolution, which is far superior to the $\mathrm{Ni}(\mathrm{OH})_{2}$ electrode and $10 \%$ commercial Pt/C-coated carbon cloth electrode. The OER performance was evaluated with $\mathrm{NiFe}(\mathrm{OH})_{2}$, which exhibits a distinct $\mathrm{Ni}^{\mathrm{II} / \mathrm{III}}$ redox transition at $\sim 1.39 \mathrm{~V}$ vs. RHE, and a prominent OER activity with an onset potential of $\sim 1.47 \mathrm{~V}$ vs. RHE. 


\section{Hydrogen and oxygen production during decoupled water splitting}

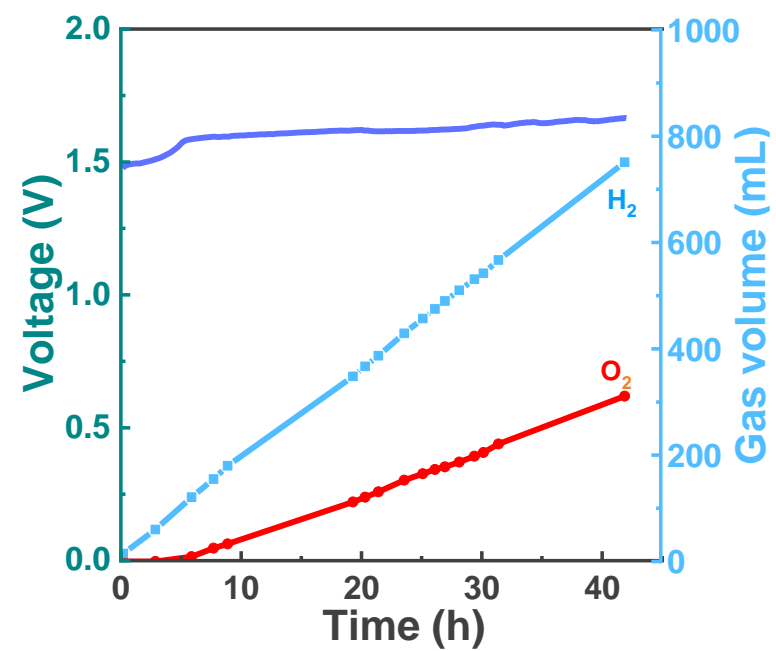

Figure S9. Voltage profile of an electrolytic flow cell during a continuous operation for $42 \mathrm{~h}$ at $10 \mathrm{~mA} / \mathrm{cm}^{2}$, and the cumulative production of $\mathrm{H}_{2}$ and $\mathrm{O}_{2}$ in the packed-bed catalytic reactor.

An anion-exchange membrane (Fumasep FAAM-15) was used as the separator. The posolyte consisted of $25 \mathrm{~mL} 0.4 \mathrm{M} \mathrm{K}_{4} \mathrm{Fe}(\mathrm{CN})_{6}$ and $0.2 \mathrm{M} \mathrm{K}_{3} \mathrm{Fe}(\mathrm{CN})_{6}$ in $4 \mathrm{M} \mathrm{NaOH}$, while $25 \mathrm{~mL} 0.2 \mathrm{M}$ DHPS in $4 \mathrm{M} \mathrm{NaOH}$ was used as negolyte. The electrolytes were circulated through the cell stack and tanks using peristaltic pumps. 5 pieces of $\mathrm{Pt}-\mathrm{Ni}(\mathrm{OH})_{2}$ catalyst $\left(1 \times 1 \mathrm{~cm}^{2}\right)$ and 5 pieces of $\mathrm{NiFe}(\mathrm{OH})_{2}$ catalyst $\left(1 \times 1 \mathrm{~cm}^{2}\right)$ were added in the cathodic tank and andic tank, respectively. The current density was $10 \mathrm{~mA} / \mathrm{cm}^{2}$. Gases produced in the tank were collected by water displacement method. Two measuring cylinders were filled with water and placed upside-down in a water bath. The gas produced in the tank was fed into the water-filled measuring cylinder through a silicone tube. The gas production was determined by the volume of displaced water in the measuring cylinder. 


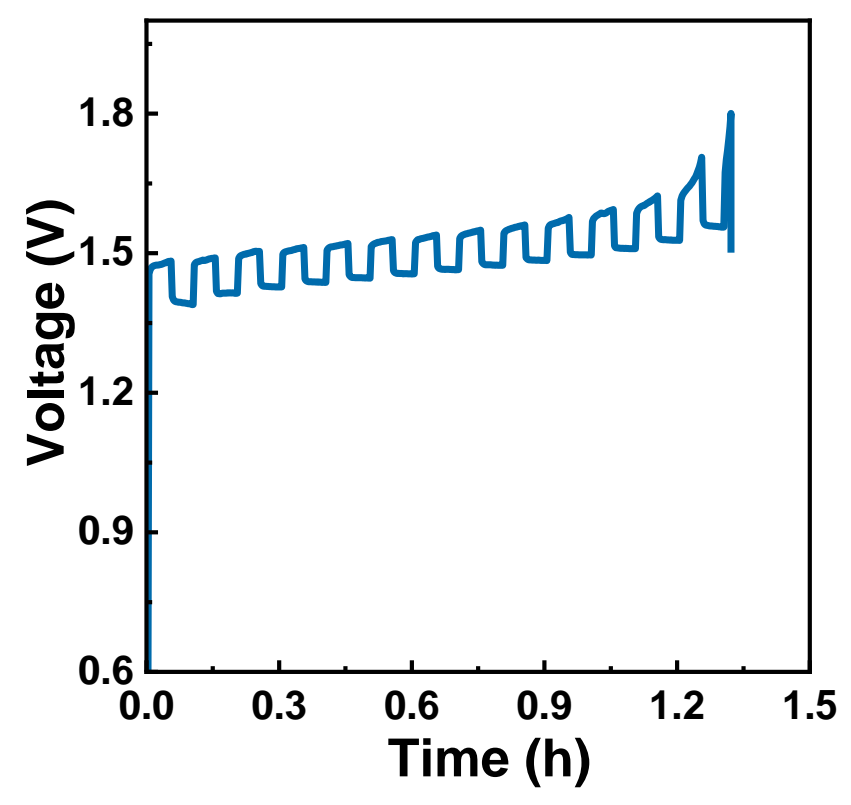

Figure S10. GITT curve of an electrolytic flow cell without catalyst during the charging process.

The electrolytic flow cell was further studied by galvanostatic intermittent titration technique (GITT), for which a current density of $40 \mathrm{~mA} / \mathrm{cm}^{2}$ was repeatedly applied for 3 min followed by 3 min relaxation (Figure S10). This cell was assembled as the normal redox-flow battery without catalyst in the tanks. An anion-exchange membrane (Sustainion ${ }^{\circledR}$ X37-50 membrane) was used as the separator. The posolyte consisted of $12 \mathrm{~mL} 0.4 \mathrm{M} \mathrm{K}_{4} \mathrm{Fe}(\mathrm{CN})_{6}$ and $0.2 \mathrm{M}$ $\mathrm{K}_{3} \mathrm{Fe}(\mathrm{CN})_{6}$ in $4 \mathrm{M} \mathrm{NaOH}$, and the negolyte consisted of $12 \mathrm{~mL} 0.2 \mathrm{M}$ DHPS in $4 \mathrm{M} \mathrm{NaOH}$. The electrolytes were circulated through the cell stack and tanks using peristaltic pumps. 


\section{Comparison of two different anion-exchange membranes}
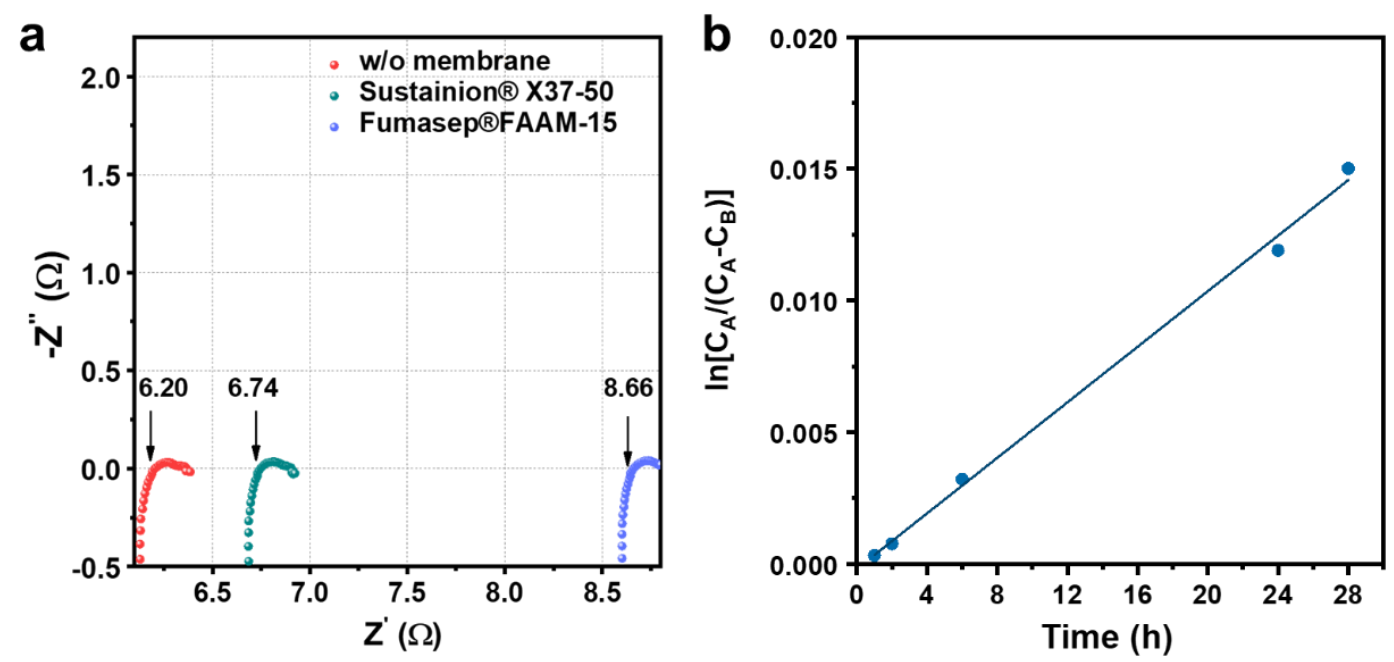

Figure S11. (a) Electrochemical impedance spectroscopic analysis of $\mathrm{H}$-cell with and without membrane. The electrolyte is $4 \mathrm{M} \mathrm{NaOH}$ solution. All the experiments were conducted on an electrochemical station (Autolab PGSTAT30) with a frequency range of 0.1 to $10^{6} \mathrm{~Hz}$. (b) Plot of $\ln \left(C_{A} /\left(C_{A}-C_{B}\right)\right)$ vs. time when using Sustainion ${ }^{\circledR} X 37-5$ membrane. $C_{A}$ is the concentration of DHPS in concentrated side $(\mathrm{mol} / \mathrm{L}) ; \mathrm{C}_{B}$ is the concentration of DHPS in deficiency side (mol/L). The enrichment cell was filled with $25 \mathrm{~mL} \mathrm{0.1} \mathrm{M} \mathrm{DHPS/4} \mathrm{M} \mathrm{NaOH}$, and the deficiency cell was filled with $30 \mathrm{~mL} 4 \mathrm{M} \mathrm{NaOH}$ solution. The area of the membrane between the two cell compartments is $2 \mathrm{~cm}^{2}$.

As shown in Figure S11a, the resistance of Sustainion ${ }^{\circledR}$ X $37-50$ membrane is only $1.08 \Omega \cdot \mathrm{cm}^{2}$, which is $4.92 \Omega \cdot \mathrm{cm}^{2}$ for fumasep®FAAM-15 membrane. However, the ion permselectivity of DHPS molecule through fumasep®FAAM-15 membrane is much better than Sustainion ${ }^{\circledR}$ X37-5 membrane. We used a H-cell setup, in which two cell compartments are separated by the membrane, to assess the ion permselectivity. The concentration of DHPS in the deficiency cell was monitored by UV-vis measurement after different durations. No DHPS was detected in the deficiency cell even after $24 \mathrm{~h}$ when using fumasep®FAAM-15 membrane. In comparison, the Sustainion ${ }^{\circledR}$ X37-5 membrane presented relatively large crossover (Figure S11b). The crossover of DHPS shouldn't present a big concern considering the oxidized DHPS molecule does not have further reaction in the posolyte in the electrolytic flow cell. 


\section{Operando UV-vis spectroscopic measurement}

UV-vis spectra of the electrolytes from an operational electrolytic flow cell were collected with a SHIMADZU UV-1800 spectrometer. The setup is shown in Figure S12. A customdesigned spectroelectrochemical cell with $10 \mu \mathrm{m}$ optical path length was connected to the anodic or cathodic flow channel outlet of the flow cell. $4 \mathrm{M} \mathrm{NaOH}$ solution was used as the blank. When testing the operando UV-vis spectroscopic measurements of negolyte, a posolyte consisting of $50 \mathrm{~mL} 0.2 \mathrm{M} \mathrm{K}_{3} \mathrm{Fe}(\mathrm{CN})_{6}$ and $0.4 \mathrm{M} \mathrm{K}_{4} \mathrm{Fe}(\mathrm{CN})_{6}$ in $4 \mathrm{M} \mathrm{NaOH}$ and a negolyte consisting of $12 \mathrm{~mL} 0.2 \mathrm{M}$ DHPS in $4 \mathrm{M} \mathrm{NaOH}$ were used. 5 pieces of $\mathrm{Pt}-\mathrm{Ni}(\mathrm{OH})_{2}$ catalyst $(1$ $\times 1 \mathrm{~cm}^{2}$ ) were settled in the negolyte tank. When testing the operando UV-vis spectroscopic measurements of posolyte, a posolyte consisting of $12 \mathrm{~mL} 0.2 \mathrm{M} \mathrm{K}_{3} \mathrm{Fe}(\mathrm{CN})_{6}$ and $0.4 \mathrm{M}$ $\mathrm{K}_{4} \mathrm{Fe}(\mathrm{CN})_{6}$ in $4 \mathrm{M} \mathrm{NaOH}$ and a negolyte consisting of $25 \mathrm{~mL} 0.2 \mathrm{M}$ DHPS in $4 \mathrm{M} \mathrm{NaOH}$ were used. 5 pieces of $\mathrm{NiFe}(\mathrm{OH})_{2}$ catalyst $\left(1 \times 1 \mathrm{~cm}^{2}\right)$ were settled in the tank. The cell was charged at $10 \mathrm{~mA} / \mathrm{cm}^{2}$.
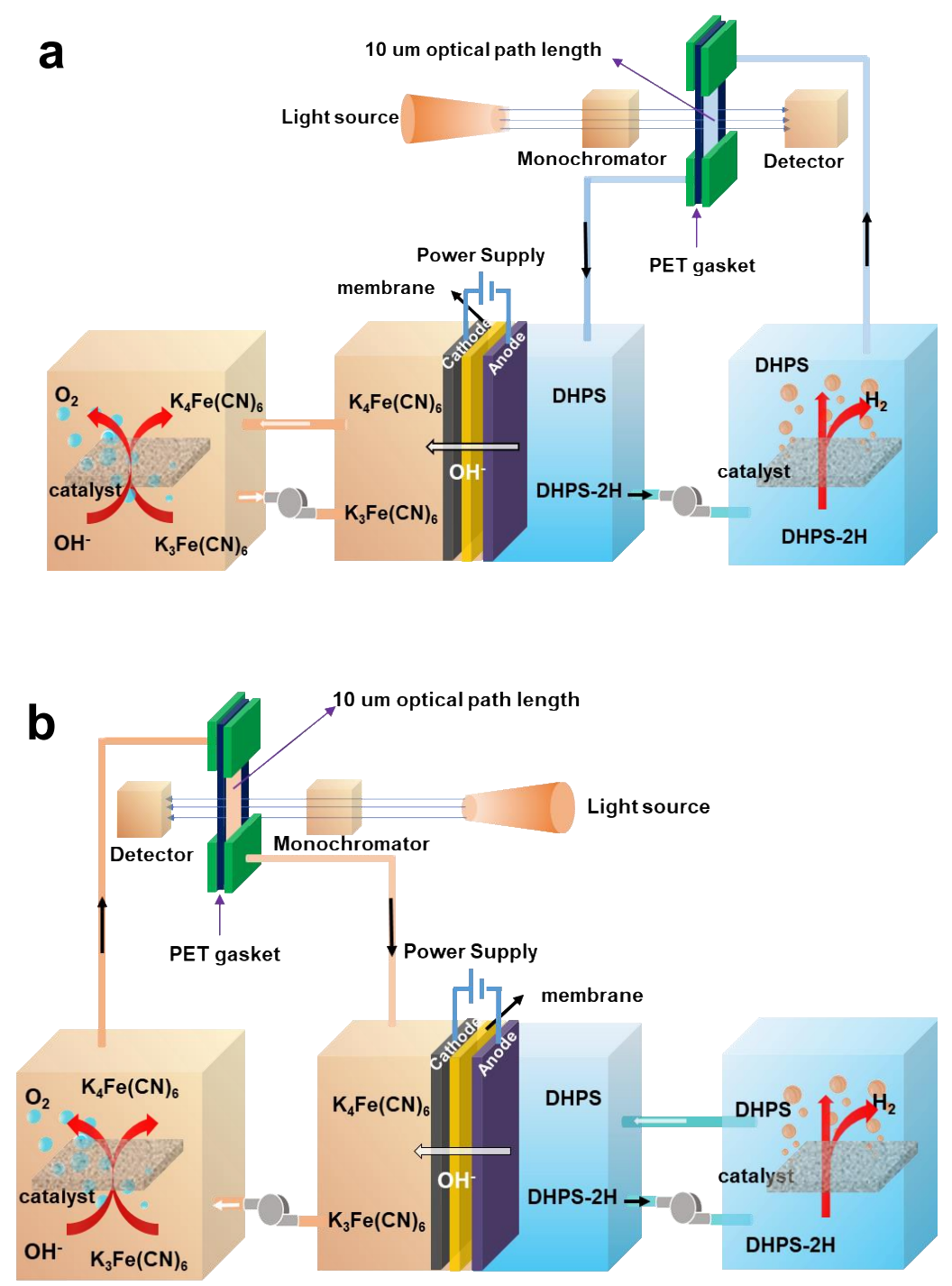

Figure S12. Configuration of the spectroelectrochemical setup for operando UV-vis spectroscopic measurements of (a) negolyte and (b) posolyte. 
a

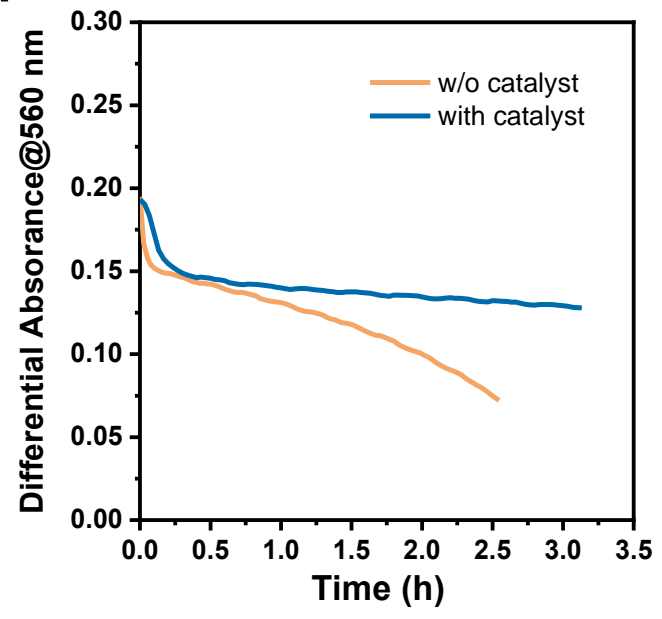

b

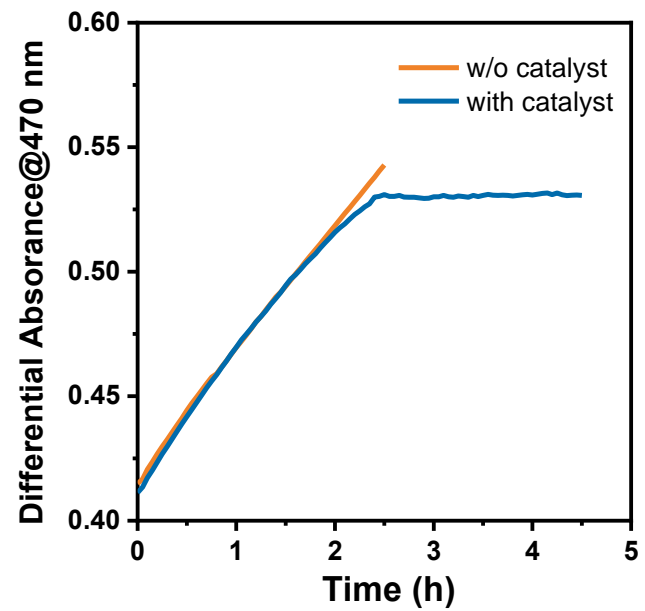

Figure S13. Absorbance changes of (a) DHPS at $560 \mathrm{~nm}$ and (b) $\left[\mathrm{Fe}(\mathrm{CN})_{6}\right]^{3-}$ at $470 \mathrm{~nm}$ in respective electrolyte upon charging a cell with/without catalyst. The charging current was 10 $\mathrm{mA} / \mathrm{cm}^{2}$. Note that as the color of DHPS is very dark, a low concentration negolyte $(0.2 \mathrm{M})$ was used here. For unknown reason, reproducibly, the absorbance of DHPS dropped quickly in the beginning of test. Nevertheless, the difference in absorbance changes induced by the catalytic HER reaction is obvious. 


\section{Comparison of decoupled and direct water splitting}
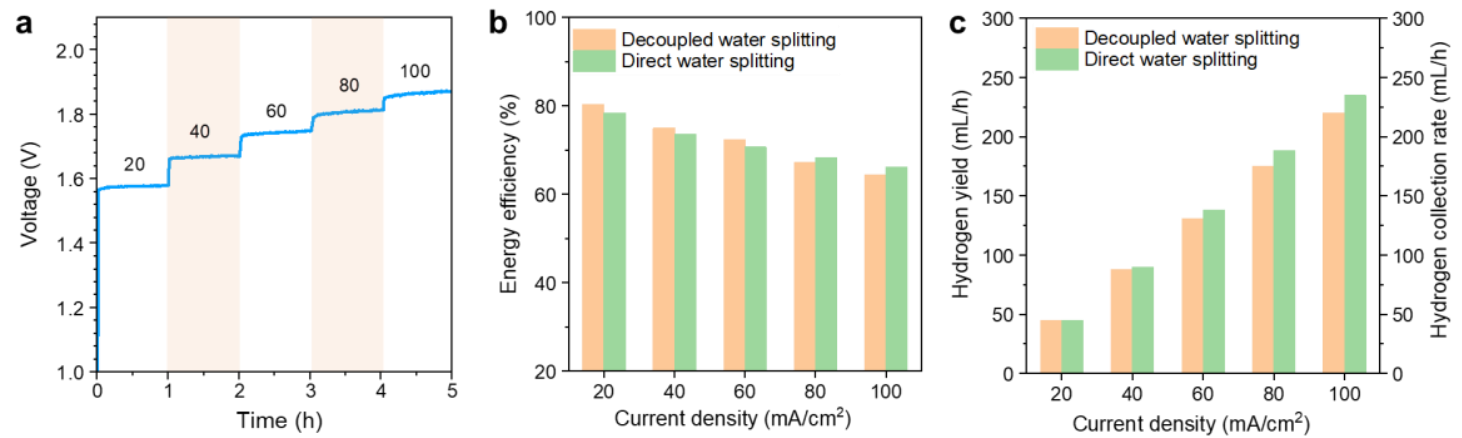

Figure S14. (a) Voltage profile of the direct water splitting with an electrolytic cell using the same HER/OER catalysts at different current densities. The current density is varied from 20 to $100 \mathrm{~mA} / \mathrm{cm}^{2}$, the electrode area is $5 \mathrm{~cm}^{2}$. The comparison of overall energy efficiency (b), $\mathrm{H}_{2}$ yield and collection rate (c) between decoupled and direct water splitting.

The voltage profile of direct water splitting using the same setup as decoupled water splitting is shown in Figure 14a. The electrolyte is $50 \mathrm{~mL} 4 \mathrm{M} \mathrm{NaOH}$. The overall energy efficiency, $\mathrm{H}_{2}$ yield and collection rate of decoupled and direct water splitting are shown in Figure S14b-c.

The overall energy efficiency was calculated as $\xi=\frac{1.23 \mathrm{~V}}{E_{\text {cell voltage }}} \times 100 \%$, where $1.23 \mathrm{~V}$ corresponds to the theoretical water splitting voltage. The overall energy efficiency of decoupled water splitting is higher than the direct one at 20,40 and $60 \mathrm{~mA} / \mathrm{cm}^{2}$. That of decoupled water splitting including $\mathrm{H}_{2}$ yield is a little lower than the direct one at relatively high current due to the fact that it still need time to generate sufficient DHPS-2H in the electrolyte before the $\mathrm{H}_{2}$ production rate in the reactor catches up and becomes balanced initially. At a longer duration (when the amount of charge is sufficiently more than the amount of DHPS in the reaction), the two methods should present rather identical $\mathrm{H}_{2}$ production yield. 


\section{DFT calculations of DHPS-mediated HER reaction}

\section{Gibbs free energy change $(\Delta G)$ of the dehydrogenation of DHPS-2H.}

The dehydrogenation reaction of DHPS- $2 \mathrm{H}$ is:

$$
\mathrm{DHPS}-2 \mathrm{H} \stackrel{\mathrm{Pt}-\mathrm{Ni}(\mathrm{OH})_{2}}{\longrightarrow} D H P S+\mathrm{H}_{2} \uparrow
$$

The thermodynamic voltage corresponding to this reaction is $-0.05 \mathrm{~V}$ derived from the redox potential difference between DHPS/DHPS- $2 \mathrm{H}$ and $\mathrm{H}_{2}$, the change of the Gibbs free energy $\Delta G^{0}$ can be calculated by the following equation,

$$
\Delta G^{0}=\mathrm{nEF}
$$

where $\mathrm{n}=2$, which is the number of transferred electrons and $\mathrm{F}$ is the Faraday constant (96485 $\mathrm{C} / \mathrm{mol}$ ), then the Gibbs free energy change of the dehydrogenation process from DHPS-2H to DHPS and $\mathrm{H}_{2}$ is determined to be $0.10 \mathrm{eV}$.

\section{Reaction mechanism of dehydrogenation of DHPS-2H.}

The dehydrogenation of DHPS-2H on Pt catalyst active sites can be split into the following elementary steps:

$$
\begin{gathered}
\text { DHPS- } 2 H \rightarrow D H P S-H+H^{*} \\
\text { DHPS }-H \rightarrow D H P S+H^{*} \\
H^{*}+H^{*} \rightarrow H_{2}
\end{gathered}
$$

where ${ }^{*}$ stands for an adsorption site on the catalyst surface. Please note the above reaction steps are shown as the sequential dehydrogenation of DHPS-2H for the formation of $\mathrm{H}_{2}$. In practice, reactions $\mathrm{S} 3$ and $\mathrm{S} 4$ may proceed in parallel to generate $\mathrm{H}^{*}$ for reaction $\mathrm{S} 5$.

In this study, the first dehydrogenation step (S3) of DHPS-2H leads to four possible intermediates, losing a hydrogen atom that is bonded to $\mathrm{O}\left(\mathrm{O}_{1}-\mathrm{H}\right.$ or $\left.\mathrm{O}_{2}-\mathrm{H}\right)$ or $\mathrm{N}\left(\mathrm{N}_{3}-\mathrm{H}\right.$ or $\mathrm{N}_{4-}$ $\mathrm{H})$. Accordingly, there are four possible pathways of the first dehydrogenation step (as shown in Figure S15).

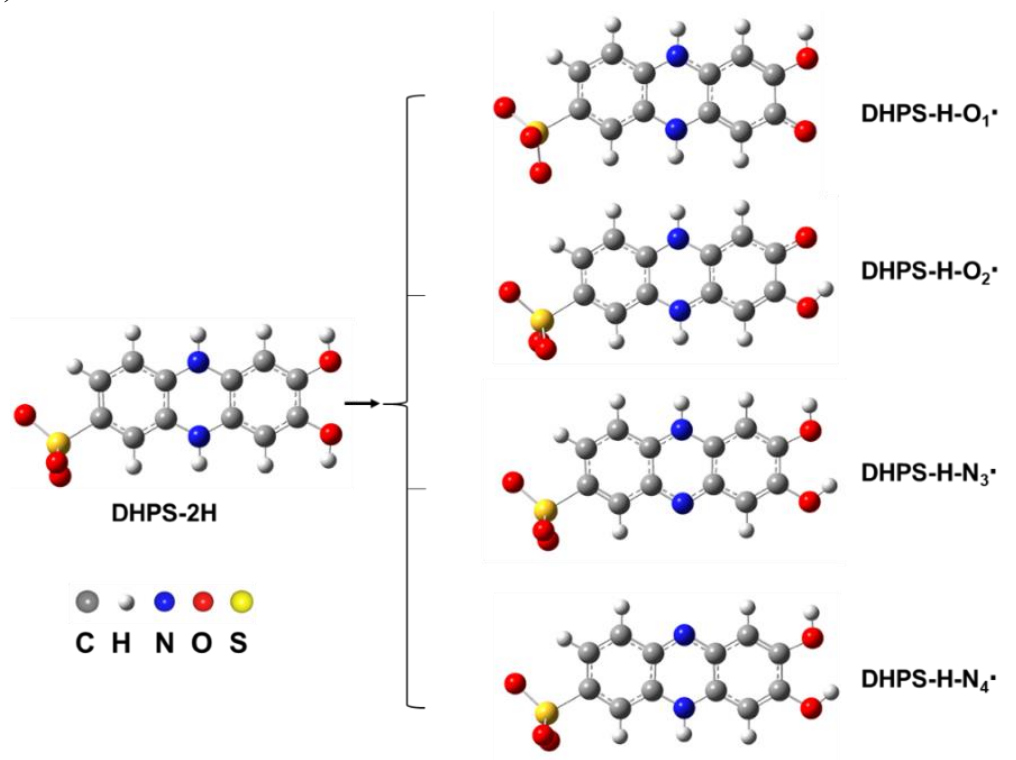

Figure S15. Four possible reaction pathways of the first dehydrogenation step of DHPS-2H. 
The reaction free energies for the dehydrogenation steps are regarded as the values of activation barriers, which qualitatively represent the right relative energetic ordering of the various protontransfer elementary steps. ${ }^{6}$ In order to determine the possible reaction pathway and the associated intermediates during HER, the reaction free energy of each elementary step through different reaction pathways during the dehydrogenation of DHPS-2H on $\mathrm{Pt}$ (111) surface should be calculated. The Gibbs reaction free energy $\Delta G$ is defined as the difference between free energies of the initial and final states, which are given by the expressions:

$$
\begin{gathered}
\Delta G_{1}=\Delta E_{1}+\Delta Z P E_{1}-T \Delta S_{1} \\
\Delta E_{1}=E_{D H P S-H}-E_{D H P S-2 H}+0.5 \times E_{H_{2}} \\
\Delta Z P E_{1}=Z P E_{D H P S-2 H}-Z P E_{D H P S-H}+0.5 Z P E_{H_{2}} \\
T \Delta S_{1}=\mathrm{T} S_{D H P S-2 H}-T S_{D H P S-H}+0.5 T S_{H_{2}}
\end{gathered}
$$

where $E$ is the reaction energy of molecules adsorbed on catalyst surface, obtained from DFT calculations; $T$ is the temperature and $\Delta S$ is the entropy change. Here, $T S_{H_{2}}=0.41 \mathrm{eV}$, and $Z P E_{\mathrm{H}_{2}}=0 \mathrm{eV}$. The vibrational frequencies of adsorbed species (DHPS-2H, DHPS- $\mathrm{H}$, and $\mathrm{H}_{2}$ ) through different reaction pathways were calculated with the model Pt (111) surface that remains fixed to obtain zero-point energy (ZPE).

\begin{tabular}{|c|c|c|c|c|c|}
\hline Species & $E(e V)$ & ZPE (eV) & $\mathrm{S}(\mathrm{Cal} / \mathrm{mol} \mathrm{K})$ & $G(e V)$ & $\Delta \mathbf{G}_{1}(\mathrm{eV})$ \\
\hline DHPS-2H & -1032.12 & 5.72 & 136.40 & 1028.15 & \\
\hline DHPS-H-O $_{1}$ & -1027.79 & 5.27 & 132.32 & 1024.22 & 0.48 \\
\hline DHPS-H-O & -1027.66 & 5.35 & 131.92 & 1023.99 & 0.70 \\
\hline DHPS-H-N ${ }_{3}$. & -1027.70 & 5.33 & 133.12 & 1024.07 & 0.62 \\
\hline DHPS-H-N ${ }_{4}$ & -1027.67 & 5.33 & 133.62 & 1024.06 & 0.64 \\
\hline
\end{tabular}

Table S1. Values used for the free energy, entropy, zero-point energy corrections and Gibbs reaction free energy in determining the free energy of intermediate species in the first dehydrogenation step of DHPS-2H.

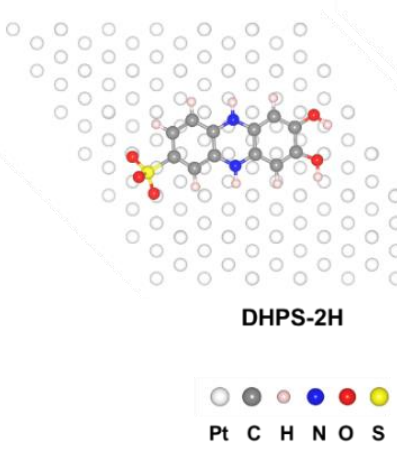

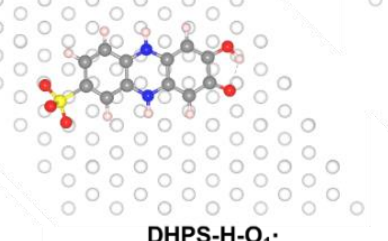

DHPS-H-O ${ }^{\text {. }}$

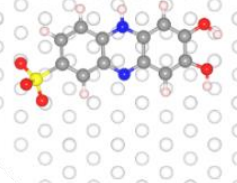

DHPS-H- $\mathrm{N}_{3}$.
DHPS- $-\mathrm{H}_{2}$.

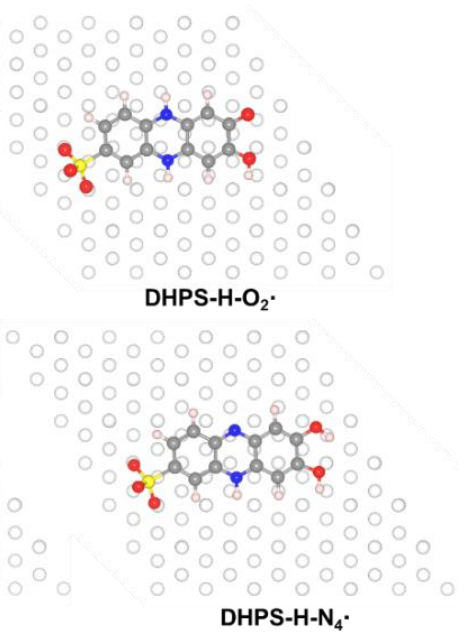

DHPS-H-N ${ }_{4}$.

Figure S16. Models of the adsorption configuration of DHPS-2H on Pt (111) surface and possible HER intermediates formed at the first step of dehydrogenation reaction.

Hence, the intermediate DHPS- $\mathrm{H}-\mathrm{O}_{1} \cdot$ which loses a hydrogen atom that is bonded to O1, due 
to its lowest Gibbs free energy change, is the most stable intermediate during the first dehydrogenation step. Based on the intermediate DHPS- $\mathrm{H}-\mathrm{O}_{1} \cdot$, there are three possible reaction pathways to lose a second hydrogen atom at the second dehydrogenation step. Considering the structure of DHPS-N 3 which lose one hydrogen atom at N3 site does not exist, there are only two possible pathways as depicted in Figure S17.
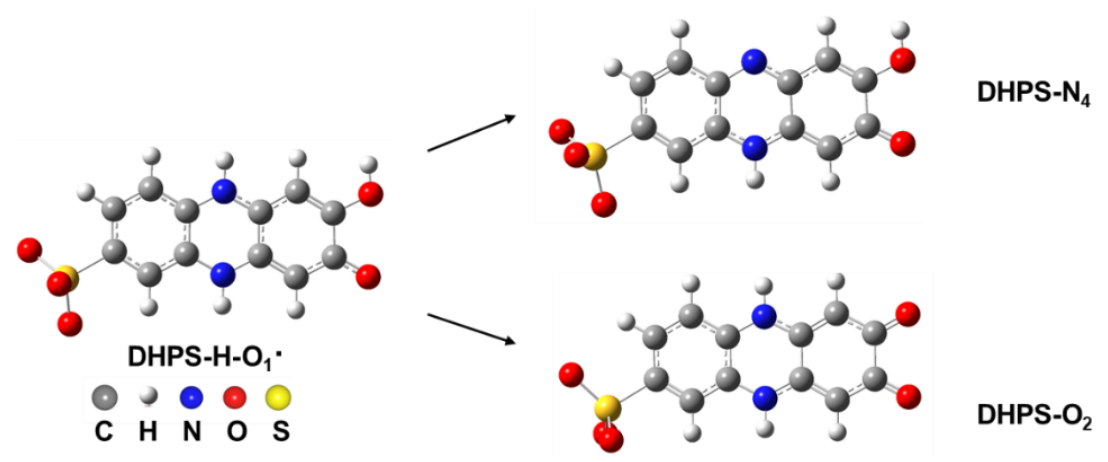

Figure S17. Two possible reaction pathways of the second dehydrogenation step from DHPS$\mathrm{H}-\mathrm{O}_{1}$.

$\Delta G$ of DHPS- $\mathrm{N}_{4}$ and DHPS- $\mathrm{O}_{2}$ are defined as the difference between free energies of the initial and final states, which are given by the expressions:

$$
\begin{array}{r}
\Delta G_{2}=\Delta E_{2}+\Delta Z P E_{2}-T \Delta S_{2} \\
\Delta E_{2}=\Delta E_{D H P S^{\prime}}-E_{D H P S-H}+0.5 \times E_{H_{2}} \\
\Delta Z P E_{2}=Z P E_{D H P S^{\prime}}-Z P E_{D H P S-H}+0.5 Z P E_{H_{2}} \\
T \Delta S_{2}=T S_{D H P S^{\prime}}-T S_{D H P S-H}+0.5 T S_{H_{2}}
\end{array}
$$

Table S2. Values used for the free energy, entropy, zero-point energy corrections and Gibbs reaction free energy in determining the free energy of intermediate species in the second dehydrogenation step of DHPS-2H.

\begin{tabular}{lccccc}
\hline Species & $\mathbf{E}(\mathbf{e V})$ & $\mathbf{Z P E}(\mathbf{e V})$ & $\mathbf{S}(\mathbf{C a l} / \mathbf{m o l} \mathbf{K})$ & $\mathbf{G}(\mathbf{e V})$ & $\Delta \mathbf{G}_{\mathbf{2}}(\mathbf{e V})$ \\
\hline DHPS-H-O $_{\mathbf{1}} \cdot$ & -1027.79 & 5.27 & 132.32 & 1024.22 & \\
\hline DHPS-O $_{2} \cdot$ & -1022.85 & 4.91 & 130.49 & 1019.61 & 1.16 \\
\hline DHPS-N $_{\mathbf{4}} \cdot$ & -1022.93 & 4.92 & 128.09 & 1019.64 & 1.12 \\
\hline
\end{tabular}

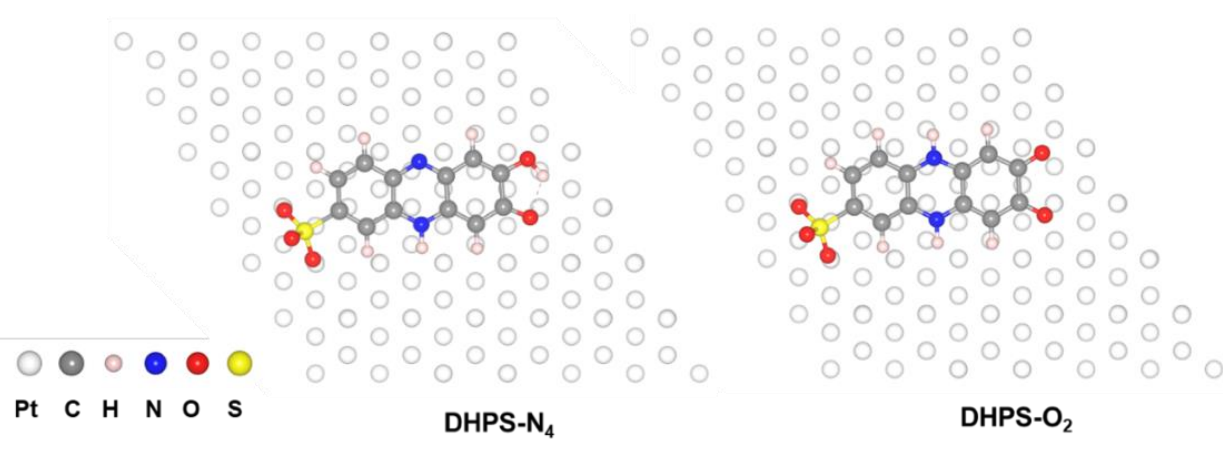

Figure S18. Models of the adsorption configuration of DHPS-N $\mathrm{N}_{4}$ and $\mathrm{DHPS}_{-} \mathrm{O}_{2}$ on Pt (111) surface formed at the second step of dehydrogenation reaction. 
The reaction free energy of DHPS-N ${ }_{4}$ is lower than that of DHPS- $\mathrm{O}_{2}$, which indicates that the dehydrogenation of DHPS-H-O $\mathrm{O}_{1} \cdot$ is energetically favorable to produce DHPS-N 4 .

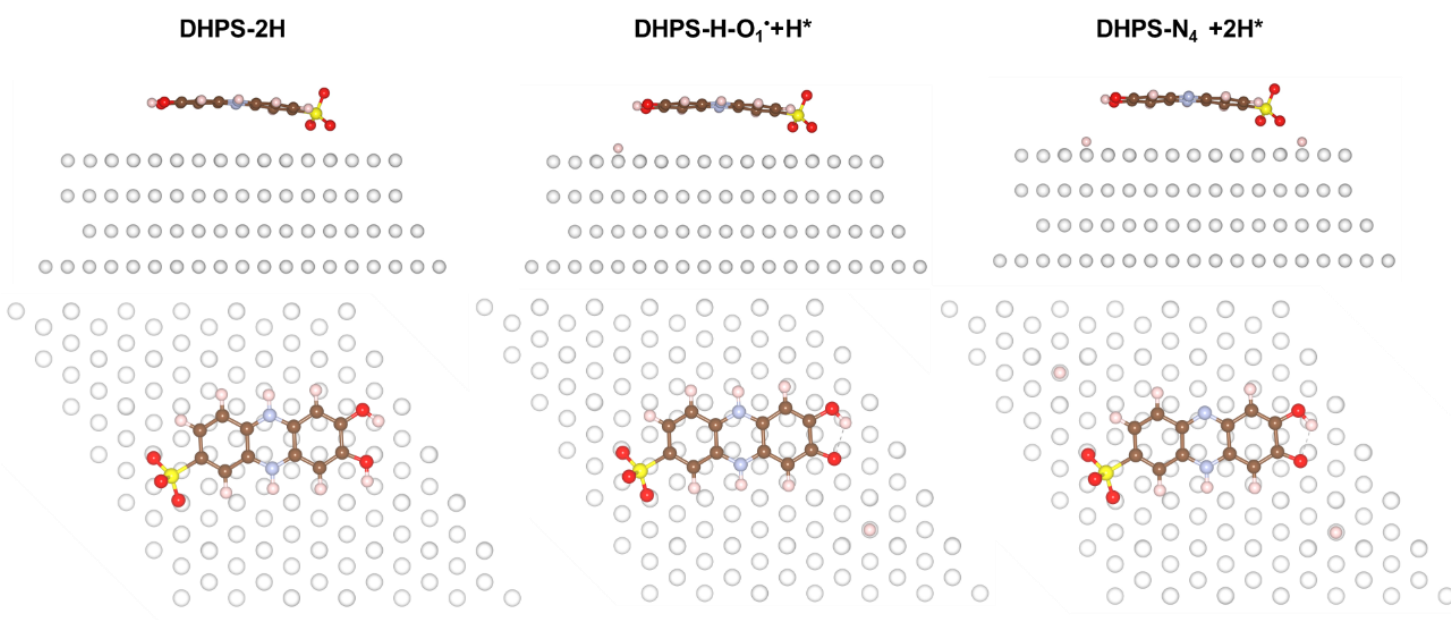

Figure S19. Reactant, intermediate and product structures (top and side-views) on Pt (111) surface for the dehydrogenation of DHPS-2H. The red, pink, brown, blue, yellow and white spheres represent $\mathrm{O}, \mathrm{H}, \mathrm{C}, \mathrm{N}, \mathrm{S}, \mathrm{Pt}$ atoms, respectively.

\section{DFT calculation of HER on the electrode.}

In alkaline HER, the first step is catalytic dissociation of a water molecule with the generation of $\mathrm{H}^{*}\left(\mathrm{H}_{2} \mathrm{O}+e^{-} \rightarrow \mathrm{OH}^{-}+\mathrm{H}^{*}\right)$. Without considering the $\mathrm{pH}$ of the solution, the energy barrier is

$$
\Delta E=E\left(\mathrm{OH}^{-}\right)+0.5 \times E_{\mathrm{H}_{2}}-E\left(\mathrm{H}_{2} \mathrm{O}\right)=0.96 \mathrm{eV}
$$

After $\mathrm{pH}$ correction, the energy barrier at $\mathrm{pH}=14.6$ is

$$
\Delta E=E\left(\mathrm{OH}^{\prime}\right)+0.5 \times E_{\mathrm{H}_{2}}-E\left(\mathrm{H}_{2} \mathrm{O}^{\prime}\right)+p H k_{B} T \ln 14.6=1.87 \mathrm{eV}
$$

where $k_{B}$ is the Boltzmann constant and $\mathrm{T}$ is the temperature. ${ }^{6}$

For the DHPS,

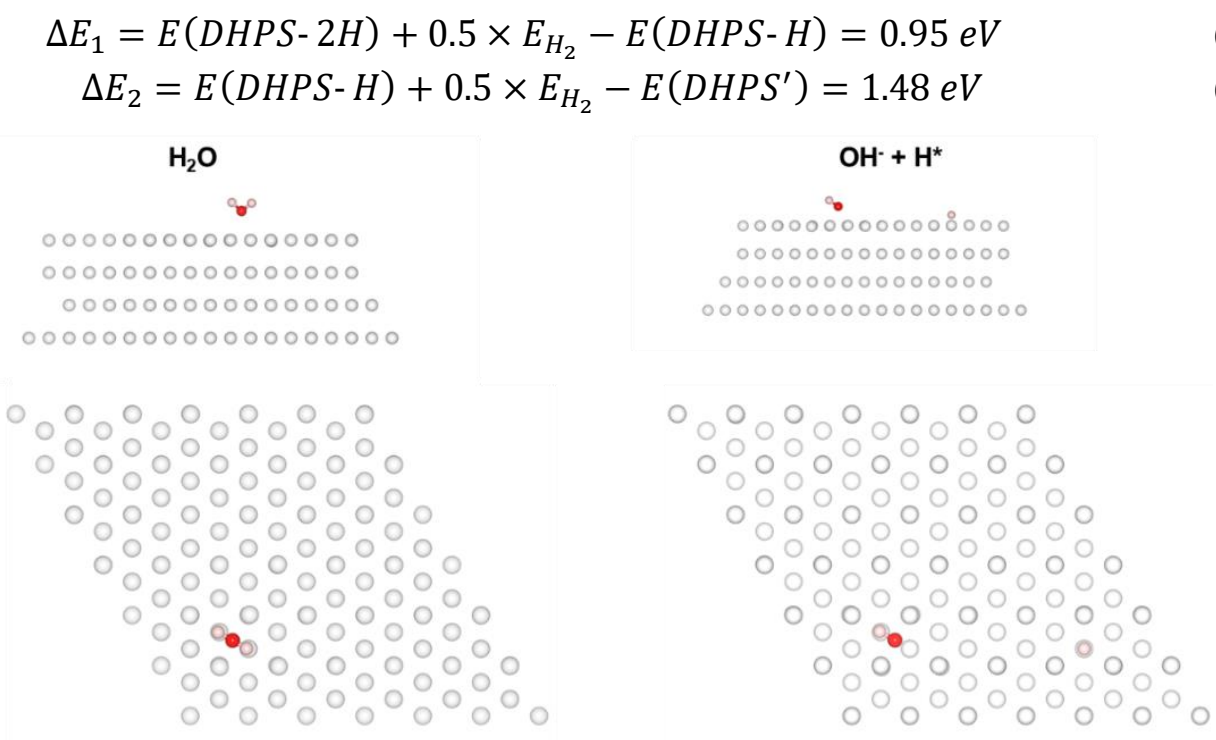

Figure S20. The initial state $\left(\mathrm{H}_{2} \mathrm{O}\right)$ and the final state $\left(\mathrm{OH}^{-}+\mathrm{H}^{*}\right)$ structures (top and side-views) on $\mathrm{Pt}$ (111) surface. The red, pink and white spheres represent $\mathrm{O}, \mathrm{H}, \mathrm{Pt}$ atoms, respectively. 
After the formation of $\mathrm{H}^{*}$ on $\mathrm{Pt}$, the formation of $\mathrm{H}_{2}$ molecule on $\mathrm{Pt}$ is studied.

Based on the Tafel reaction, $H^{*}+H^{*} \rightarrow H_{2}$,

$$
\Delta G_{\text {Tafel }}=G_{P t(111)}+0.5 \times G_{H_{2}}-G_{H^{*}}=0.109 \mathrm{eV}
$$

Based on the Heyrovsky reaction, $H^{*}+D H P S-2 H \rightarrow H_{2}+D H P S-H-O_{1}$,

$$
\Delta G_{\text {Heyrovsky }}=G_{\text {DHPS-H-01. }}+G_{H_{2}}-G_{H^{*}+\mathrm{DHPS}-2 \mathrm{H}}=0.738 \mathrm{eV}
$$

Therefore, the Tafel reaction is more energetically favorable for the formation of $\mathrm{H}_{2}$ molecule.

Table S3. Values used for the free energy, entropy, zero-point energy corrections and Gibbs

\begin{tabular}{|c|c|c|c|c|}
\hline Species & $E(e V)$ & ZPE (eV) & TS (eV) & $G(e V)$ \\
\hline Pt (111) & -840.12 & 0 & 0 & -840.12 \\
\hline $\mathbf{H}^{*}$ & -843.82 & 0.14 & 0 & -843.68 \\
\hline $\mathbf{H}_{2}$ & -6.77 & 0.27 & 0.41 & -6.90 \\
\hline DHPS-2H + H* & -1035.96 & 5.85 & 1.76 & -1031.88 \\
\hline DHPS-H-O ${ }_{1}$ & -1027.79 & 5.26 & 1.71 & -1024.23 \\
\hline
\end{tabular}
reaction free energy of intermediate species during Heyrovsky reaction. 
X. EPR measurement of DHPS-2H upon dehydrogenation

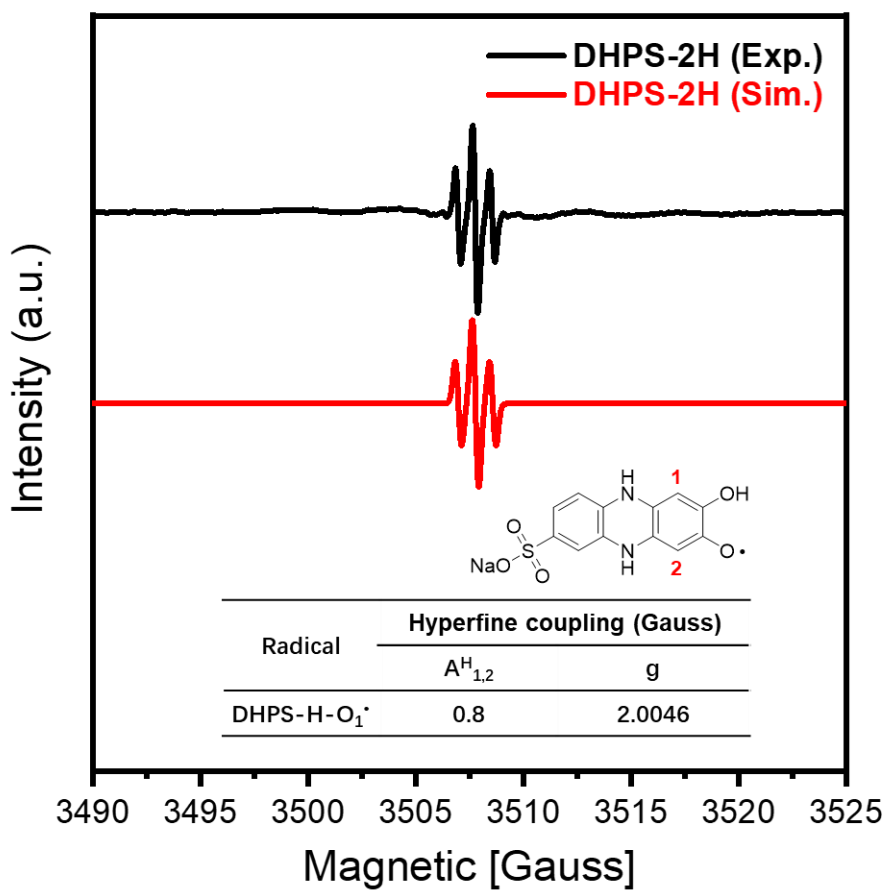

Figure S21. EPR experimental and simulated spectra of dehydrogenated DHPS-2H in the presence of Pt catalyst. 
XI. NMR measurement of DHPS-2H upon dehydrogenation

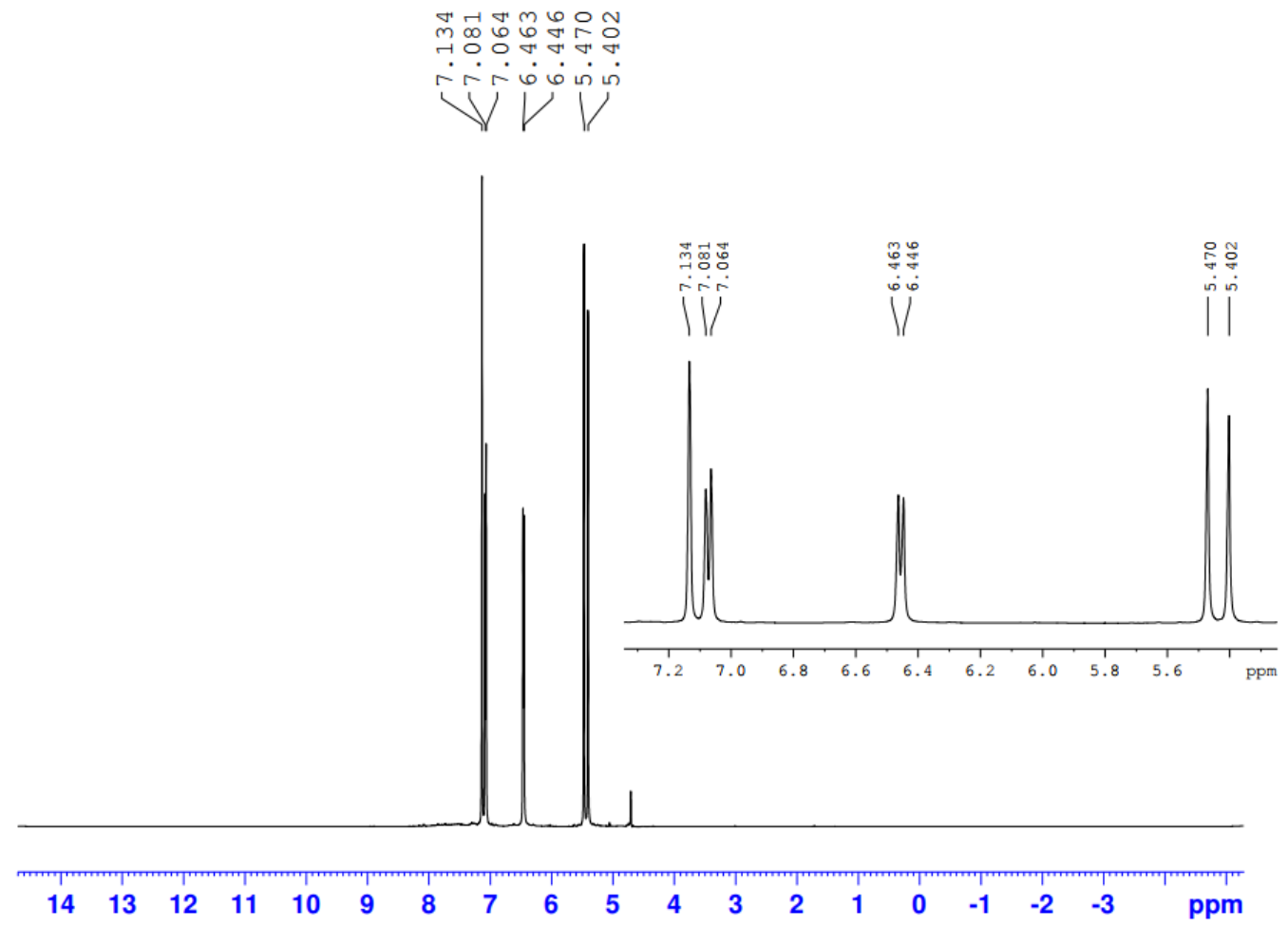

Figure S22. ${ }^{1} \mathrm{H}-\mathrm{NMR}$ spectrum of standard $1 \mathrm{M}$ DHPS in $2 \mathrm{M} \mathrm{NaOH}$ aqueous solution recorded in $\mathrm{D}_{2} \mathrm{O}(10 \mathrm{vol} . \%)$. For comparison purpose, a standard $1 \mathrm{M}$ DHPS in $2 \mathrm{M} \mathrm{NaOH}$ solution was prepared. The exchangeable protons $(-\mathrm{NH},-\mathrm{OH})$ were not detected due to the aqueous conditions. 


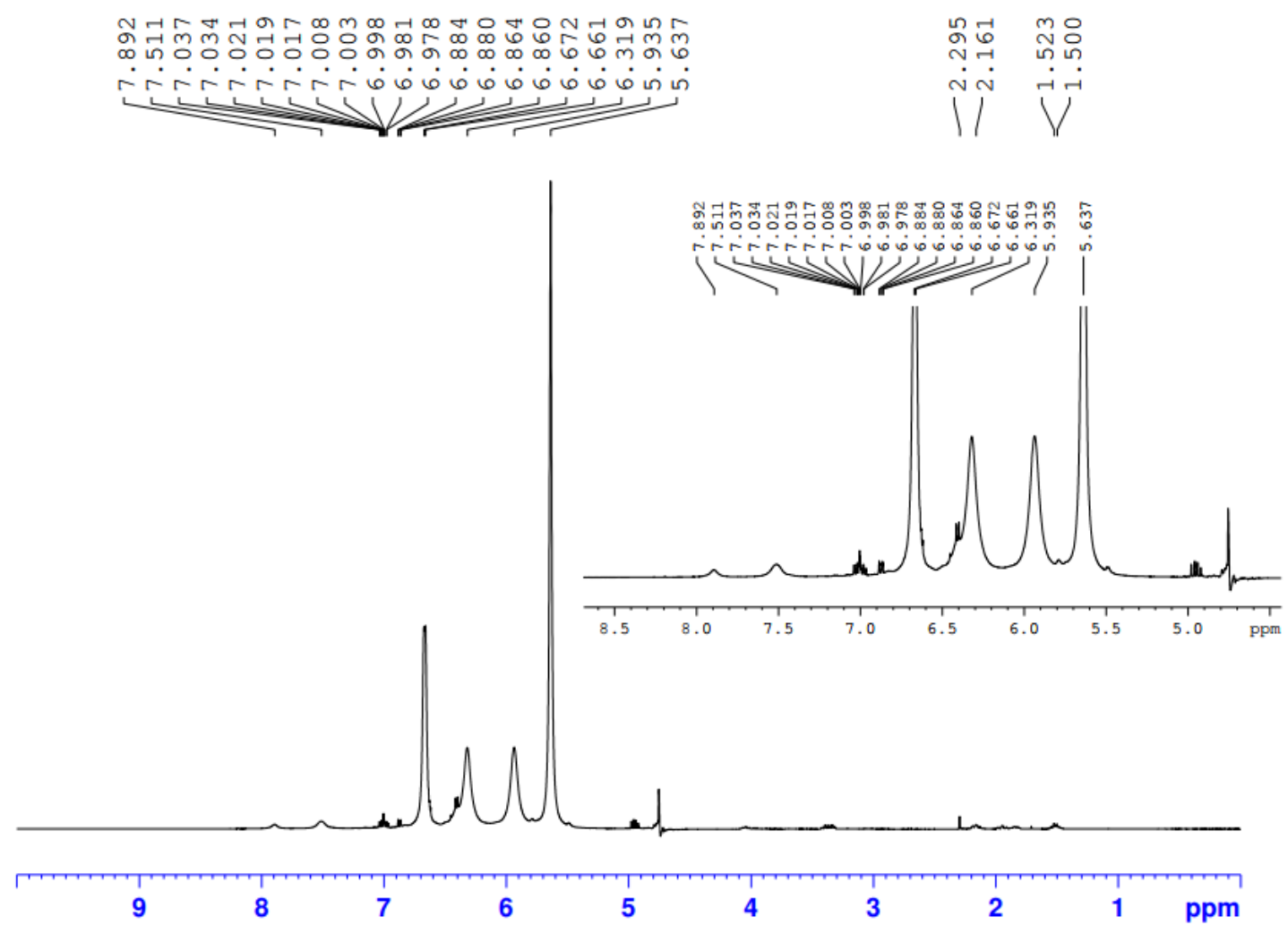

Figure S23. ${ }^{1} \mathrm{H}-\mathrm{NMR}$ spectrum of DHPS-2H recorded in $\mathrm{D}_{2} \mathrm{O}$. The DHPS-2H was obtained by charging $1 \mathrm{M} \mathrm{DHPS} / 2 \mathrm{M} \mathrm{NaOH}$ in a normal redox flow battery. $0.5 \mathrm{~mL}$ completely reduced DHPS solution was taken out, added with $\mathrm{D}_{2} \mathrm{O}(10 \mathrm{vol} . \%)$ and sealed in the NMR testing tube. Both the charging and sealing processes were operated in the $\mathrm{N}_{2}$-filled grove box. 


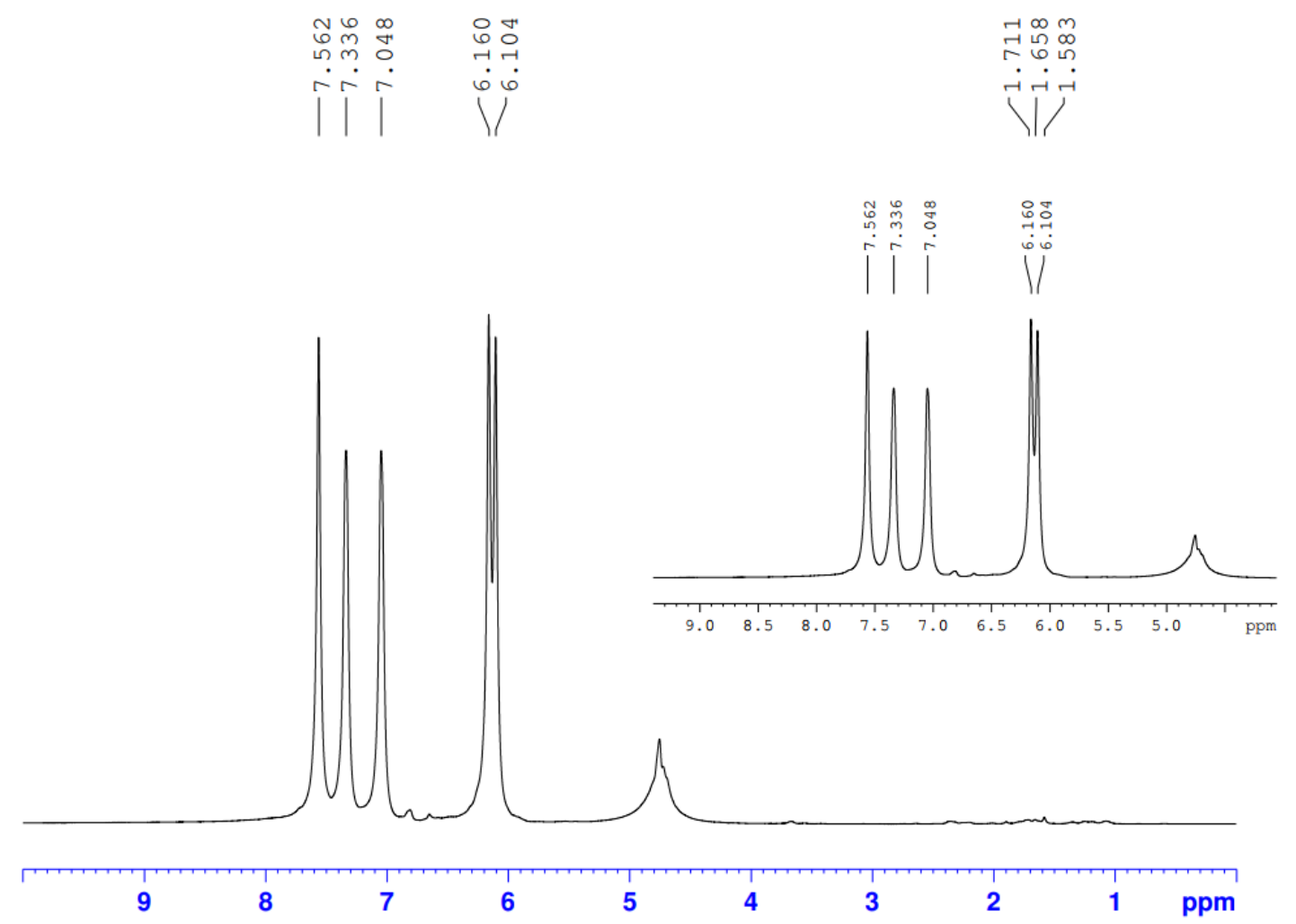

Figure S24. ${ }^{1} \mathrm{H}-\mathrm{NMR}$ spectrum of DHPS-2H after reacted with Pt catalyst recorded in $\mathrm{D}_{2} \mathrm{O}$. The above completely reduced DHPS $(0.5 \mathrm{~mL})$ was taken out and added with $2 \mathrm{~cm}^{2} \mathrm{Pt}-\mathrm{Ni}(\mathrm{OH})_{2}$ catalyst under stirring for $4 \mathrm{~h}$. The bubbles were generated at first and then disappeared. Taken out the DHPS-2H solution after HER reaction without catalyst, added in $\mathrm{D}_{2} \mathrm{O}(10$ vol.\%) and sealed in the NMR testing tube. All the processes were operated in a $\mathrm{N}_{2}$-filled grove box. 
XII. Comparison of different decoupled water splitting methods

Table S4. Comparison of the spatially decoupled water electrolyzer reported here with other decoupled water splitting systems reported in literature.

\begin{tabular}{|c|c|c|c|c|c|}
\hline Redox mediators & Catalyst & Electrolyte & $\begin{array}{l}\text { Total voltage for } \\
\text { water splitting }\end{array}$ & $\begin{array}{l}\text { Energy Efficiency } \\
\qquad \begin{array}{c}\left(\xi=\frac{1.23 \mathrm{~V}}{E_{\text {cell voltage }}} \times\right. \\
100 \%)\end{array}\end{array}$ & Reference \\
\hline $\begin{array}{c}\mathrm{Fe}(\mathrm{CN}) 6^{4-/ 3-} \\
/ \mathrm{DHPS}\end{array}$ & $\begin{array}{l}\mathrm{Pt} / \mathrm{Ni}(\mathrm{OH})_{2} \text { for } \\
\mathrm{HER} \\
\mathrm{NiFe}(\mathrm{OH})_{2} \text { for } \\
\mathrm{OER}\end{array}$ & $4 \mathrm{M} \mathrm{NaOH}$ & $\begin{array}{c}1.53,1.70, \text { and } \\
1.91 \mathrm{~V}(20,60, \\
\text { and } 100 \\
\left.\mathrm{~mA} / \mathrm{cm}^{2}\right)\end{array}$ & $\begin{array}{c}80.4,72.4, \text { and } \\
64.4 \\
(20,60, \text { and } 100 \\
\left.\mathrm{mA} / \mathrm{cm}^{2}\right)\end{array}$ & $\begin{array}{l}\text { This } \\
\text { work }\end{array}$ \\
\hline $\mathrm{H}_{3} \mathrm{PMo}_{12} \mathrm{O}_{40}$ & $\begin{array}{l}\text { Pt for HER and } \\
\text { OER }\end{array}$ & $1 \mathrm{M} \mathrm{H}_{3} \mathrm{PO}_{4}$ & $\begin{array}{c}2.94 \mathrm{~V} \\
\left(100 \mathrm{~mA} / \mathrm{cm}^{2}\right)\end{array}$ & 41.8 & {$[\mathrm{~S} 7]^{7}$} \\
\hline $\mathrm{H}_{4}\left[\mathrm{SiW}_{12} \mathrm{O}_{40}\right]$ & $\begin{array}{l}\text { Pt for HER and } \\
\text { OER }\end{array}$ & $1 \mathrm{M} \mathrm{H}_{3} \mathrm{PO}_{4}$ & $\begin{array}{c}2.21 \mathrm{~V} \\
\left(50 \mathrm{~mA} / \mathrm{cm}^{2}\right)\end{array}$ & 55.7 & {$[\mathrm{~S} 8]^{8}$} \\
\hline $\begin{array}{c}\text { V(II)/V(III) } \\
\mathrm{Ce}(\mathrm{III}) / \mathrm{Ce}(\mathrm{IV})\end{array}$ & $\begin{array}{l}\mathrm{Mo}_{2} \mathrm{C} \text { for HER } \\
\mathrm{RuO}_{2} \text { for OER }\end{array}$ & $1 \mathrm{M} \mathrm{H}_{2} \mathrm{SO}_{4}$ & $\begin{array}{c}2.5 \mathrm{~V} \\
\left(60 \mathrm{~mA} / \mathrm{cm}^{2}\right)\end{array}$ & 49.2 & {$[\mathrm{~S} 9]^{9}$} \\
\hline $\mathrm{FcNCl}$ & $\begin{array}{c}\mathrm{Ni}_{2} \mathrm{P} / \mathrm{Ni} \text { for HER } \\
\mathrm{Ni} \text { for OER }\end{array}$ & $0.5 \mathrm{M} \mathrm{Na}_{2} \mathrm{SO}_{4}$ & $\begin{array}{c}2.43 \mathrm{~V} \\
\left(10 \mathrm{~mA} / \mathrm{cm}^{2}\right)\end{array}$ & 50.6 & {$[\mathrm{~S} 10]^{10}$} \\
\hline $\mathrm{NiOOH} / \mathrm{Ni}(\mathrm{OH})_{2}$ & $\begin{array}{l}\mathrm{RuO}_{2} / \mathrm{IrO}_{2} \text {-Ti-mesh } \\
\text { for OER and Pt-Ti- } \\
\text { mesh for HER }\end{array}$ & $1 \mathrm{M} \mathrm{NaOH}$ & $\begin{array}{c}1.98 \mathrm{~V} \\
\left(10 \mathrm{~mA} / \mathrm{cm}^{2}\right)\end{array}$ & 62.1 & {$[\mathrm{~S} 11]^{11}$} \\
\hline $\begin{array}{c}\mathrm{NiOOH} / \mathrm{Ni}(\mathrm{OH})_{2} \\
\left(25 \text { and } 95^{\circ} \mathrm{C}\right)\end{array}$ & $\begin{array}{c}\mathrm{Ni}_{0.9} \mathrm{Co}_{0.1}(\mathrm{OH})_{2} \text { for } \\
\text { OER and } \mathrm{Ni} \text { for } \\
\text { HER }\end{array}$ & $\begin{array}{c}0.6 \mathrm{M} \mathrm{K}_{2} \mathrm{CO}_{3} \\
\text { and } 0.4 \mathrm{M} \\
\mathrm{KHCO}_{3}\end{array}$ & $\begin{array}{l}1.44,1.50,1.56 \\
\text { and } 1.60 \mathrm{~V} \\
(10,50,100 \text { and } \\
\left.200 \mathrm{~mA} / \mathrm{cm}^{2}\right)\end{array}$ & $\begin{array}{c}85.4,82.0,78.7 \\
\text { and } 76.8 \% \\
(10,50,100 \text { and } \\
\left.200 \mathrm{~mA} / \mathrm{cm}^{2}\right)\end{array}$ & {$[\mathrm{S} 12]^{12}$} \\
\hline
\end{tabular}




\section{References}

1. Hollas, A.; Wei, X.; Murugesan, V.; Nie, Z.; Li, B.; Reed, D.; Liu, J.; Sprenkle, V.; Wang, W., A biomimetic high-capacity phenazine-based anolyte for aqueous organic redox flow batteries. Nature Energy 2018, 3 (6), 508-514.

2. Pan, F.; Huang, Q.; Huang, H.; Wang, Q., High-Energy Density Redox Flow Lithium Battery with Unprecedented Voltage Efficiency. Chemistry of Materials 2016, 28 (7), 2052-2057.

3. Wu, H.; Zhu, T.; Lu, X.; Ho, G. W., High-efficient electrocatalysts by unconventional acidetching for overall water splitting. Journal of Materials Chemistry A 2017, 5(46), 24153-24158.

4. Mao, L.; Guan, C.; Huang, X.; Ke, Q.; Zhang, Y.; Wang, J., 3D Graphene-Nickel Hydroxide Hydrogel Electrode for High-Performance Supercapacitor. Electrochimica Acta 2016, 196, 653660.

5. Hadden, J. H. L.; Ryan, M. P.; Riley, D. J., Is Nickel Hydroxide Charging Only Skin-Deep? ACS Applied Energy Materials 2020, 3 (3), 2803-2810.

6. Yang, L.; Cheng, D.; Xu, H.; Zeng, X.; Wan, X.; Shui, J.; Xiang, Z.; Cao, D., Unveiling the highactivity origin of single-atom iron catalysts for oxygen reduction reaction. Proc Natl Acad Sci US A 2018, 115 (26), 6626-6631.

7. Symes, M. D.; Cronin, L., Decoupling hydrogen and oxygen evolution during electrolytic water splitting using an electron-coupled-proton buffer. Nat Chem 2013, 5 (5), 403-9.

8. Rausch, B.; Symes, M. D.; Chisholm, G.; Cronin, L., Decoupled catalytic hydrogen evolution from a molecular metal oxide redox mediator in water splitting. Science 2014, 345 (6202), 1326 30.

9. Amstutz, V.; Toghill, K. E.; Powlesland, F.; Vrubel, H.; Comninellis, C.; Hu, X.; Girault, H. H., Renewable hydrogen generation from a dual-circuit redox flow battery. Energy Environ. Sci. 2014, 7(7), 2350-2358.

10. Li, W.; Jiang, N.; Hu, B.; Liu, X.; Song, F.; Han, G.; Jordan, T. J.; Hanson, T. B.; Liu, T. L.; Sun, Y., Electrolyzer Design for Flexible Decoupled Water Splitting and Organic Upgrading with Electron Reservoirs. Chem 2018, 4 (3), 637-649.

11. Chen, L.; Dong, X.; Wang, Y.; Xia, Y., Separating hydrogen and oxygen evolution in alkaline water electrolysis using nickel hydroxide. Nat Commun 2016, 7, 11741.

12. Dotan, H.; Landman, A.; Sheehan, S. W.; Malviya, K. D.; Shter, G. E.; Grave, D. A.; Arzi, Z.; Yehudai, N.; Halabi, M.; Gal, N.; Hadari, N.; Cohen, C.; Rothschild, A.; Grader, G. S., Decoupled hydrogen and oxygen evolution by a two-step electrochemical-chemical cycle for efficient overall water splitting. Nature Energy 2019, 4 (9), 786-795. 